\title{
Showing off cleaner hands: mandatory climate-related disclosure by financial institutions and the financing of fossil energy
}

\author{
Jean-Stéphane Mésonnier ${ }^{1}$, Benoit Nguyen ${ }^{2}$
}

\author{
January 2021, WP \#800
}

\begin{abstract}
We investigate the real effects of mandatory climate-related disclosure by financial institutions on the funding of carbon-intensive industries. Our impact metric is the amount invested into securities, bonds and stocks, issued by fossil fuel companies. A French law, which came into force in January 2016 in the aftermath of the Paris Agreement on climate change, provides us with a quasi-natural experiment. The new regulation, unique in Europe at that time, requires institutional investors (i.e., insurers, pension funds and asset management firms), but not banks, to report annually on both their climate-related exposure and climate change mitigation policy. Using a unique dataset of security-level portfolio holdings by each institutional sector in each euro area country, we compare the portfolio choices of French institutional investors with those of French banks and all financial institutions located in other EA countries. We find that investors subject to the new disclosure requirements curtailed their financing of fossil energy companies by some $40 \%$ compared to investors in the control group.
\end{abstract}

Keywords: Bilan carbone, investisseurs institutionnels, énergie fossile, désinvestissement.

JEL classification: G11, G15, G23, H55, Q54, Q56.

\footnotetext{
${ }^{1}$ Jean-Stéphane Mésonnier : Banque de France and Chair Energy and Prosperity, Risk Foundation (email: jean-stephane.mesonnier@,banque-france.fr).

${ }^{2}$ Benoit Nguyen : Banque de France (email : benoit.nguyen@banque-france.fr).

We are grateful to Henri Fraisse and Guillaume Vuillemey for insightful discussions and to seminar participants at Banque de France for their comments.
} 


\section{NON-TECHNICAL SUMMARY}

Following calls for action to financial institutions at the Paris summit in December 2015 (COP21), coalitions for sustainable finance have urged investors to enhance their climate-related disclosure on a voluntary basis. In this paper, we ask instead whether imposing a mandatory disclosure to financial institutions actually leads them to divest from carbon-intensive securities. We study the effects of a recent French law (article 173-6 of the TECV law, for Transition Energétique et Croissance Verte, in english Energy Transition and Green Growth), which pioneered such regulation on climate-related disclosure. Passed in August 2015 in the run-up to the COP21, the law entered into force as soon as January 2016. This new regulation - unique at that time - imposes on institutional investors registered in France a new detailed reporting on both their exposure to climate-related risks and their efforts to mitigate climate change.

We focus on investors' holdings of securities, bonds and stocks, issued by firms in the fossil energy industry, responsible for the bulk of global greenhouse gas (GHG) emissions. In 2019, coal, oil and natural gas accounted for $81 \%$ of world primary energy supply according to the IEA, for $75 \%$ of global GHG emissions and $90 \%$ of carbon dioxide emissions. We first construct an exhaustive dataset of all securities, bonds and stocks, issued by fossil energy companies worldwide and outstanding during the period from 2013 Q4 to 2019 Q3. We select them from two industry classifications: Thomson Reuters' Business Classification (TRBC) and Bloomberg's Industry Classification system (BICS). In a second step, we merge this list of securities with Securities Holdings Statistics (SHS), a unique proprietary dataset of the Eurosystem which covers the entire universe of securities (bonds and stocks) held by investors domiciliated in the euro area.

We first provide new information about the financing of the global fossil energy industry. Euro area investors as a whole held in September 2019 around EUR 600 billion of securities issued by 2,157 fossil energy firms worldwide. Investments into the fossil energy sector by euro area financial institutions have grown (in market value terms) since 2013, from EUR 377 billion to EUR 488 billion at the end of our period.

Figure : Effect of mandatory climate-related disclosure on boldings of fossils energy securities by financial institutions

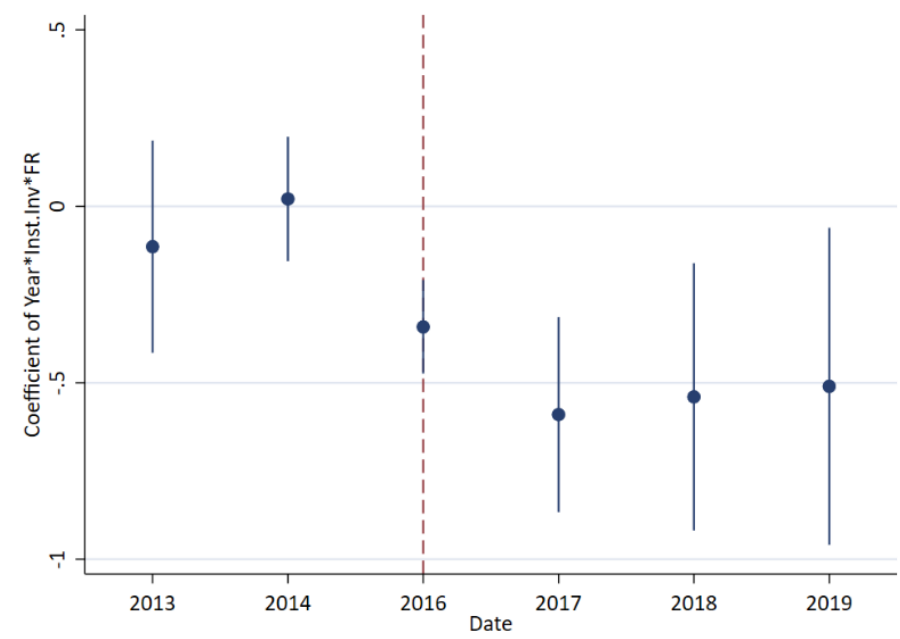

Note: The vertical dotted bar materializes the implementation of the French TECV law (from January 2016 on), which imposes climate-related disclosure on French institutional investors. 2015 is set as the reference value. This figure plots the coefficient of a panel regression in which the left hand side variable is the log of market value holdings, and the right hand side the interaction of French treated intitutional investors and year. We control for security-year, holder sector-time, holder country-time and sector-country fixed effects

We then exploit this dataset to analyze the consequences of the French TECV law of 2015. The granularity of our data allow us for a proper causal identification of its effects on the amount of funding allocated into the fossil energy industry. The provisions of article 173-6 explicitly target two 
types of financial institutions: insurance companies and pension funds, and all other asset management firms and mutual investment funds, commonly dubbed "institutional investors", but not banks. This provides us with neat treated and control groups of holder sectors: we compare, before and after December 2015, the holdings of individual fossil energy securities by institutional investors in France (treated) with those by banks in France and all financial sub-sectors in all other countries (controls).

We find evidence of a sharp relative decrease in holdings of fossil energy securities in the portfolios of treated investors once the TECV law is implemented, as compared to holdings by our control group. The effect of the mandatory climate-related disclosure on investments into these carbonintensive companies is strongly significant, both statistically and economically. Our results points to a relative reduction in holdings by $39 \%$ on average in the portfolios of treated investors. Considering the volume of outstanding investments into fossil energy by French institutional investors at the end of 2015 as a reference point, this suggests EUR 28 billion of fundings have been redirected out of this industry by treated investors (mutatis mutandis).

\title{
Obligation de transparence des institutions financières sur leur empreinte climatique et financement des énergies fossiles
}

\begin{abstract}
RÉSUMÉ
Nous étudions les effets réels d'une obligation de transparence de l'empreinte climatique des institutions financières sur leur financement des industries carbonées, en nous concentrant sur les montants investis dans les titres (actions et obligations) émis par les entreprises fossiles. Une loi française entrée en vigueur à partir de Janvier 2016 à la suite des Accords de Paris nous fournit une expérience quasi-naturelle. Cette nouvelle réglementation, unique en Europe sur la période, impose aux investisseurs institutionnels (assurances, fonds de pension et sociétés de gestion), mais pas aux banques, de rendre compte chaque année de leur exposition aux risques climatiques ainsi que de la contribution de leur politique d'investissement à la transition énergétique. Nous utilisons des données originales de détention de portefeuille titre par titre par secteur et pays de la zone euro, et comparons les choix de portefeuille des investisseurs institutionnels français avec ceux des investisseurs non concernés par la loi (institutions financières des autres pays de la zone euro et empreinte carbone, obligation de transparence, énergie fossile, investisseurs institutionnels banques Françaises). Nous trouvons que les investisseurs soumis à la nouvelle réglementation ont réduit leur financement des énergies fossiles de près de $40 \%$ en termes relatifs par rapport au groupe de contrôle.
\end{abstract}

Mots-clés: Empreinte carbone, obligation de transparence, énergie fossile, investisseurs institutionnels.

Les Documents de travail reflètent les idées personnelles de leurs auteurs et n'expriment pas nécessairement la position de la Banque de France. Ils sont disponibles sur publications.banque-france.fr 


\section{Introduction}

Curbing global greenhouse gas emissions to reach the objectives set in the Paris Agreement requires a major shift of global funding towards low-carbon activities. How to achieve rapidly enough this re-allocation of private capital is an open issue. Following calls for action to financial institutions at the Paris summit in December 2015 (COP21), coalitions for sustainable finance have flourished in the financial industry, urging their members to enhance the disclosure of their exposure to climate-related risks and/or to reduce the carbon footprint of their investments. ${ }^{1}$ Yet, such kind of disclosure is not regulatory-binding in most countries and environmental NGOs regularly decry the financial industry's statements of intent as mere greenwashing. ${ }^{2}$

In this paper, we ask whether imposing more stringent disclosure standards on financial institutions regarding the carbon footprint of their portfolios actually leads them to divest from carbon-intensive securities. To provide an answer, we look at the effects of a recent French law (the so-called TECV law, for Transition Energétique et Croissance Verte, in english Energy Transition and Green Growth), which pioneered such regulation on climate-related disclosure by financial institutions in Europe. ${ }^{3}$ Passed in August 2015 in the run-up to the COP21, the law entered into force as soon as January 2016. This new regulation imposes on institutional investors registered in France (i.e., insurance companies and pension funds on the one hand, asset management firms on the other hand, but not banks) a new detailed reporting on both their exposure to climate-related risks and their efforts to mitigate climate change (e.g., by sharing their estimate of the global temperature trajectory on which their portfolio is aligned). While the list of required disclosures is comprehensive, firms are expected to answer them on a "comply or explain" basis and are free to choose their prefered evaluation methodologies.

By leaving such degree of freedom to respondants, the legislator explicitely aimed at spurring innovation and competition in new matters -the measurement of financial risks associated with climate change as well as of the contribution of financial institution to decarbonizing the real economy- where no clear benchmark has emerged yet. We avoid here entering into the complex debates about the relative merits of alternative measurement methodologies and look instead directly for the "real impact" of these new transparency requirements in terms of induced portfolio adjustments out of carbon-intensive securities. We narrow our focus to investors' holdings

\footnotetext{
${ }^{1}$ Two prominent examples are the Task Force for climate-related financial disclosure (TCFD) and the Climate Action 100+ initiative.

${ }^{2}$ See for instance the annual reports by the Rainforest Alliance Network, Banking on climate change, available at: https://www.ran.org/bankingonclimatechange2020/

${ }^{3}$ This new requirement is defined in article 173-6 of the law and is usually refered to as "compliance with article 173-6" by French market participants and supervisors.
} 
of securities, bonds and stocks, issued by firms in the fossil energy industry (i.e., firms operating in the extraction, production and transport of fossil fuels). Such a focus on the financing of fossil energy companies is vindicated by several important facts. First, it is acknowledged that the bulk of global greenhouse gas (GHG) emissions and thus global warming comes from the combustion of fossil fuels. ${ }^{4}$ Second, current production and development plans in the fossil energy industry are obviously inconsistent with the transition to a low-carbon economy which is called for by the Paris Agreement as well as the European strategy for green transition (EU Green Deal announced in 2019). ${ }^{5}$ Last, the investments of large financial institutions into fossil fuels, be they conventional ones (oil and gas) or unconventional ones (such as sand oil, shale gas and arctic drilling, and including coal), have been the object of much public scrutiny by environmental NGOs in recent years. ${ }^{6}$ Faced with increased transparency requirements on the carbon intensity of their portfolios, financial institutions have then large incentives to cut priorily their holdings of the "brownest" securities, both to meet more rapidly climate-related compliance targets, whatever the metrics used, and to make their claimed climate commmitments easier to communicate to the public (by publishing for instance plans of exiting out of coal).

To conduct our analysis, we first construct an exhaustive dataset of all securities, bonds and stocks, that were issued by fossil energy companies worldwide and were outstanding during the period from 2013 Q4 to 2019 Q3. For this purpose, we consider two industry classifications widely used by market participants: Thomson Reuters' Business Classification (TRBC) and Bloomberg's Industry Classification system (BICS). For both nomenclatures, we focus on the energy sector and pick up all securities issued by companies in sub-sectors related to fossil fuels. ${ }^{7}$ Combining both lists allows us to increase the number of relevant securities covered by our study by about one third and the holding amounts by some $15 \%$. We then map the BICS sub-sectors into the TRBC ones so as to be able to partition our list of fossil energy securities into two sub-categories: conventional oil and gas vs unconventional fossil fuels and coal. All in all, we end up with a comprehensive list of some 15,523 fossil energy securities (12,167 bonds and 3,356 stocks).

\footnotetext{
${ }^{4}$ In 2019 , coal, oil and natural gaz accounted for $81 \%$ of world primary energy supply according to the IEA, for 75\% of global GHG emissions and 90\% of carbon dioxide emissions (SEI et al., 2019).

${ }^{5}$ According to SEI et al. (ibid.), governments worldwide are planning to produce about $50 \%$ more fossil fuels by 2030 than would be consistent with a $2^{\circ} \mathrm{C}$ pathway and $120 \%$ more than would be consistent with a $1.5^{\circ} \mathrm{C}$ pathway for global temperature.

${ }^{6} \mathrm{Cf}$. for instance the report Banking on climate change 2019 published by a consortium of NGOs (RAN-OxfamFriends of the Earth).

${ }^{7}$ For instance: "Coal mining", "Oil drilling offshore", “Oil pipeline transportation”, "Petroleum refining”, "Gasoline stations", etc.
} 
In a second step, we merge this list of securities with the Securities Holdings Statistics (SHS) database, a unique proprietary dataset of the Eurosystem which covers the entire universe of securities (bonds and stocks) held by investors domiciliated in the euro area. The information on holdings is available quarterly at the individual security-level for each institutional sector (such as, e.g., households or credit institutions) in each euro area country. The dataset also includes useful complementary information about each security (e.g., market price, total capitalization, redemption date etc.).

We first provide new information about the financing of the global fossil energy industry. Euro area investors held in September 2019 a market value of some EUR 600 billion of securities issued by 2,157 fossil energy firms worldwide. This amounts to some $12 \%$ of the total market funding (bonds and stocks) of these companies. Unsurprinsingly, financial institutions (banks, insurers, pension funds and investment funds) dominate other investors (households, non-financial companies and public administrations), holding $82 \%$ of the total amount held in the euro area in September 2019. Importantly, investments into the fossil energy sector by euro area financial institutions have grown steadily (in market value terms) since 2013, from EUR 377 billion to EUR 523 billion as of September 2018. They however levelled off thereafter, to reach EUR 488 at the end of our period, which may reflect the recent commitments by many large European financial institutions to curb the carbon footprint of their business.

We then exploit this dataset to analyze the consequences of the French TECV law of 2015. The granularity of our data allows for a proper causal identification of its effects on the amount of funding allocated into the fossil energy industry. In line with the Eurosystem' statistical framework, the SHS-S dataset classifies euro area financial institutions into nine sub-sectors. ${ }^{8}$ We group these sub-sectors into three broad types of institutions: credit institutions (deposittaking institutions, in short: banks), insurance companies and pension funds (in short ICPF), and all other asset management firms and mutual investment funds (in short: AM). The provisions of article 173-6 explicitely target the last two types of financial institutions (ICPF and AM), commonly dubbed "institutional investors", but not banks. Besides, the law only applies to financial institutions domiciliated in France, while no similar legislation exists in any other euro area country before 2019. In the spirit of a triple difference-in-differences exercise, this therefore provides us with neat treated and control groups of holder sectors: we then compare, before and after December 2015, the holdings of individual fossil energy securities by institutional investors in France (treated) with those by banks in France and all financial sub-sectors in all other countries (control). We control for heterogenous average holdings of each ISIN across sector-country pairs. We saturate our empirical model with holding sector-time, country-time

${ }^{8}$ Excluding here central banks. 
and even security-year fixed effects, which absorb all possible demand-side and supply-side confounding factors.

We find evidence of a sharp relative decrease in holdings of fossil energy securities in the portfolios of France-based institutional investors once the TECV law is implemented, as compared to holdings by financial institutions in our control group. The effect of the mandatory climate-related disclosure on investments into these carbon-intensive companies is strongly significant, both statistically and economically. The estimated coefficient of the triple interaction term points to a relative reduction in holdings by $39 \%$ on average in the portfolios of treated French investors. Considering the volume of outstanding investments into fossil energy by French institutional investors at the end of 2015 as a reference point, an average cut by $39 \%$ points to some EUR 28 billion of fundings that have been redirected out of this industry by French insurance companies and pension and investment funds (mutatis mutandis). Furthermore, beyond this adjustment along the intensive margin of holdings, we also look at the extensive margin of portfolio adjustments. We find complementary evidence that treated investors are less likely to hold fossil energy securities altogether under the new regulation on climate-related disclosure.

We check for the robustness of our findings along several dimensions. First we check that our results do not hinge at the inclusion within the control group of investors of a given country (where for instance some regulatory or tax change we would be unaware of could have lifted investments into carbon-intensive securities). Second, note that our baseline test looks at changes in securities holdings, expressed in current market value. However, one would like to ensure that the estimated effect actually reflects active divestments, i.e. a decrease in volumes held and not merely price fluctuations. ${ }^{9}$ Although our baseline regressions include controls for prices, we also perform a series of additional econometric tests that show unambiguously that this is the case. Last, we explore potentially differentiated effects of the new disclosure policy along several dimensions of the data. We notably find that the impact of this regulation is about twice larger for investments in companies exploiting mostly coal and unconventional fossil fuels instead of conventional oil and gas. We also find evidence of a strong home bias in the reaction of euro area investors, since divestments by treated institutions are 3.5 times larger when it comes to reducing the exposure to non-euro area issuers.

\footnotetext{
${ }^{9}$ Note however that the average price of all fossil securities held either by treated investors or investors in the control group increased markedly in 2017, in line with broad fluctuations in European and global stock indexes, which would play against our results. For instance, as stocks are concerned, the Euro Stoxx 50 jumped by some 700 points (almost a quarter) between November 2016 and April 2017, to reach a peak at some 3,700 points on April 30th, 2017.
} 
Our study fits in the new and rapidly evolving literature dealing with climate finance (for a survey, see Hong et al., 2020). More precisely, we contribute to at least two main strands of recent research.

First, this paper fits in the abundant literature on the financial and real effects of information disclosure in financial markets. Going back to at least Stigler (1963), an important stream of research has discussed the pros and cons of the mandatory disclosure of financial information by firms that are listed on stock exchanges (see, e.g., for surveys and recent analyses Greenstone et al., 2006; Goldstein and Yang, 2017; Jayaraman and Wu, 2019). ${ }^{10}$ More recently, researchers have investigated the real effects of mandatory disclosure regarding firms' environmental, social and governance (ESG) performance (see for instance Christensen et al., 2017; Ioannou and Serafeim, 2017). More specifically, as concerns associated with climate change and environmental damages have been growing, several recent studies take a closer look at the real consequences of mandatory carbon disclosure. ${ }^{11}$ Existing studies on carbon disclosure however priorily test whether transparency regulation leads GHG emitting, non-financial companies to pollute less. Downar et al. (2019) for instance find that a 1993 regulation requiring UK-incorporated listed companies to disclose standardized information on their annual greenhouse gas (GHG) emissions led to a significant decrease in emissions (see also Jouvenot and Krueger, 2020). In contrast, our paper is however the first to investigate the effects of a regulation that mandates investors to disclose the carbon footprint of their portfolio, i.e. their indirect responsibility for the GHG emissions of the companies they fund.

Second, this study relates to the rapidly expanding stream of research that asks whether financial institutions have become more aware of climate change, and whether they act accordingly. Avalaible findings point to a mixed answer so far, although there are more and more signs that global investors are now awakening to the issue. A first type of studies look at asset prices and investigate whether investors correctly price climate-related risks. For instance, Bolton and Kacperczyk (2020b) find evidence of a carbon risk premium in the cross-section of US stocks in recent years, and Ramelli et al. (2020) show that stocks prices of high-carbon intensity firms reacted strongly to the first Global Climate Strike of March 2019. Ilhan et al. (2020) show that put option prices also reflect the downside risks associated with higher carbon emissions. Last, Koelbel et al. (2020) exploit US firms' mandatory climate-related disclosure

\footnotetext{
${ }^{10}$ As far as financial institutions are concerned, an important related issue has also been to assess the benefits and costs of revealing the results of stress tests run by bank supervisors (Goldstein and Sapra, 2014; Goldstein and Leitner, 2018; Leitner, 2014).

${ }^{11}$ Crifo and Sinclair-Desgagné (2014) survey the literature on corporate environmental responsibility (CER) and analyze reasons for firms to voluntarily implement CER programs.
} 
(to the SEC) and find that CDS spreads are responsive to this information. ${ }^{12}$ A second line of studies exploits information about investors' self-reported perception of risks and strategies and track changes in various measures of their ESG performance. For instance, Gibson and Krueger (2017) find that institutional investors with longer-term horizons exhibit better sustainability footprints, while Dyck et al. (2019) show that institutional investors push for an improved ESG performance of the firms they invest in when these investors come from countries where ESG issues are perceived as important. Looking more precisely at one such country, Boermans and Galema (2019) document that Dutch pension funds that opted for active portfolio management strategies have substantially reduced their carbon footprint by divesting from carbon-intensive industries over the last decade. ${ }^{13}$ In contrast with these papers, we look at investors's divestments from carbon-intensive industries whenever they are obliged to publicly reveal their carbon footprint. Considering the ongoing debate about the divergence of available ESG ratings (Berg et al., 2019) and climate-related metrics (Raynaud et al., 2020), we prefer to focus on changes in holdings of securities commonly viewed as "brown" instead of more sophisticated, but possibly noisy, ESG performance or temperature-alignment indicators.

The remainder of this paper is organized as follows. Section II presents the French TECV law and the institutional context in details. Section III describes our data and provides aggregate statistics on euro area holdings of fossil energy securities. Section IV explains our empirical strategy. Section V expounds our results. Last, section VI concludes.

\section{The 2015 French regulation on climate-related disclosure}

In the run-up to the COP21 conference in Paris, which led to the Paris Agreement on Climate change of December 2015, France passed on 17 August 2015 a law on Energy transition and green growth. ${ }^{14}$ In its article 176-6, this law pioneered the first mandatory disclosure by institutional investors of both their climate-related risks and their contribution to national climate change mitigation goals. This new regulation went well beyond previous regulations on ESG reporting already applying to financial firms in France and in the world alike. French legislators aimed first at making institutional investors aware of the emissions induced by their investments and the resulting financial risks. By facilitating the access to more transparent information, they also wished to enable public authorities as well as NGOs and citizens to incentivize them to align their investments with the required transition to a low-carbon economy.

\footnotetext{
${ }^{12}$ As far as bank loan spreads are concerned, Kleimeier and Viehs (2018) and Delis et al. (2018) look for evidence of a carbon risk premium in the spreads of syndicated bank loans and find somewhat conflicting results over the last decade.

${ }^{13}$ In a similar vein, Gibson et al. (2020) exploit a survey of responsible investing (RI) by institutional investors around the world and find that portfolios of European, but not US-based, RI funds exhibit higher ESG scores.

${ }^{14}$ Loi 2015-992 sur la transition énergétique pour la croissance verte, in short TECV law, available at: https : //wWw.legifrance.gouv.fr/eli/loi/2015/8/17/2015-992/jo/article_173
} 
The 2015 law was enacted by a decree published on 29 December 2015 and its provisions entered into force as soon as 1 January 2016. The decree lists the institutions that must comply with the new disclosure requirements. These are (i) asset management firms (in French, Sociétés de gestion de portefeuilles, or SGP), i.e., all types of mutual and investment funds but pension funds (in short in what follows, AM), and (ii) insurance companies and a variety of state-owned and private financial institutions managing pension funds (in short, insurance companies and pensions funds, ICPF). ${ }^{15}$

To sum up the decree, domestic institutional investors must report on three dimensions of their climate-related impact and responsibility (see, e.g., Cardona et al., 2018). First, they must measure the carbon footprint of their investment portfolio and display the greenhouse gas emissions generated by their investments. Second, they must provide a detailed analysis of their exposure to both so-called physical risks and transition risks, i.e., to potential losses due to more frequent and damaging natural disasters brought about by climate change (e.g., destruction of physical capital of the invested non-financial firms) on the one hand, and also to potential losses due to more stringent environmental policies aimed at mitigating climate change (e.g., stranded assets of invested firms which operate in the fossil energy sector). Third, investors must also measure how they themselves contribute (or not) to mitigating climate change, by sharing information about whether their portfolio aligns with a 2 degree trajectory of global climate and also by computing the green share and the brown share of their investments (i.e., in the jargon of green finance, the share of their portfolio which is invested in low-carbon and highly-emitting companies or industries, respectively). Last but not least, the regulation is meant on a "comply or explain" basis: institutions that fail to provide the required numbers and analysis must explain why they cannot comply with the law.

Since 2016 and over the years, several NGOs, think tanks and French public bodies have published assessments of how these new provisions on climate-related disclosure have been implemented by the regulated financial firms. ${ }^{16}$ These reports typically focus on the quality and sincerity of the information disseminated by the regulated institutions in their annual reports, ESG reports, specific publications dedicated to their compliance with article 173-6 of the 2015 law and their websites more generally. They converge in pointing to insufficiently detailed information, somewhat inconsistent methodologies and lack of efforts overall, at least in the first two years, while a lot of heterogeneity in commitments and compliance still prevailed as of the end of 2018. For instance, an official monitoring exercise conducted jointly by the French ministries (for Environment and Finance) and supervisory authorities (ACPR and AMF)

\footnotetext{
${ }^{15}$ See Decree 2015-1850 of 29 December 2015 for details: https://www.legifrance.gouv.fr/eli/ decret/2015/12/29/2015-1850/jo/texte. This decree also defines a threshold of EUR 500 million of total (consolidated) assets, below which the targeted institutions are allowed to comply with a simplified reporting. ${ }^{16}$ See notably Cardona et al. (2018), ACPR et al. (2019), Novethic (2017) and WWF (2017)
} 
in charge finds that only a half of the 48 largest institutions publish at least some information on all required dimensions of the mandatory disclosure (ACPR et al., 2019). In contrast with these assessment of compliance with the new legal disclosure requirements, we evaluate the impact of the mandatory climate-related transparency on investment behaviours and focus on the induced disinvestments out of fossil energy companies, a sector much scrutinized by the public for its large carbon footprint.

To conclude on institutional matters, note that the 2015 French TECV law takes part in the broader picture of a global move since at least the COP21 towards increasing the climate-related disclosure of financial institutions, be it on a voluntary or mandatory basis. A first significant initiative is the Task Force on Climate-related Financial Disclosure (TCFD), a coalition of the willing set-up in 2015 under the patronage of the G20's Financial Stability Board. The TCFD released in 2017 an influential report setting widely approved disclosure guidelines for financial institutions. While the TCFD aims at improving voluntary carbon disclosure by participating institutions, new regulations in the spirit of the French law are also in the baking at the European level in the context the EU Green Deal launched in 2019 by the van der Leyen Commission. In particular, the ongoing revision of the 2014 EU directive on non-financial reporting (NFRD) is likely to result soon in a strenghtening of mandatory carbon reporting by European financial institutions, also in line with the recommendations of the TCFD. As a first step, the EU commission published in June 2019 new guidelines on reporting climate-related information. In February 2020, the EU Commission also launched a public consultation on its renewed sustainable finance strategy. ${ }^{17}$ Importantly for the validity of our identification strategy, no extended climate-related disclosure requirements had however been implemented in the euro area, except in France, over the period of our study (2013-2019).

\section{Data}

We are interested in tracking investments in debt securities and stocks issued by fossil energy companies. To identify them, we rely on two market-based industry classifications (TRBC and BICS) which are widely used to sort companies by their activity, for instance in order to devise stock market sub-indices. In what follows we present briefly each classification and how we map them with securities holdings.

\section{A. Identifying fossil energy securities}

Thomson Reuters Business Classification (TRBC) is an industry classification developed and owned by Refinitiv (formerly Thomson Reuters) that tracks 72,000 public companies and around 250,000 securities in all asset classes. Companies are classified mainly based on their

\footnotetext{
${ }^{17}$ For further reference, please see at: https://ec.europa.eu/info/publications/
} sustainable-finance-renewed-strategy_en. 
primary source of revenue. ${ }^{18}$ TRBC classifies companies into 5 levels of granularity: economic sectors, business sectors, industry groups, industry and activities. For our purpose, we search bonds and stocks issued by companies classified in the economic sector "Energy" and the industry groups and activities related to fossil subcategories (eg. "Oil \& Gas Storage", "Natural Gas Pipeline Transportation", etc...). We recover 12,437 unique securities (9,684 bonds and 2,753 stocks) active between 2013Q4 and 2019Q3. Table A.1 gives an overview of the 31 TRBC subcategories related to fossil energy we found in our database and Appendix B shows an extract of the full classification.

The Bloomberg Industry Classification Systems (BICS) ${ }^{19}$ is an industry classification developed by Bloomberg. It is used as a reference for instance for all Barclays/Bloomberg indices used for passive investment. This classification system is based on companies' main business line, wich is identified according to each activity's contribution to net income, operating income, total assets and also incorporates some judgement or market perception. BICS includes "more than 2.5 million legal entities" and industry classification data are available for around 1.5 million securities. Companies are sorted into 10 macro sectors ("Energy", "Transportation"...), each sector being further broken down into 8 levels of classification. ${ }^{20}$ For our purpose, we select the BICS level 1 "Energy" and the BICS level 2 corresponding to industry groupings related to fossil energy (eg. "Coal Operations", "Pipeline", "Integrating oils" etc...). We retrieve 12,085 unique securities (9,998 bonds and 2,087 stocks) active between 2013Q4 and 2019Q3.

Our aim is to get a comprehensive view of the universe of outstanding fossil energy securities, using the financial industry standards. We are agnostic on which source would be the most accurate, or whether one better classifies than another. We therefore combine the two sources and keep all identified securities. All in all, our list consists of 15,523 unique securities identified by their ISIN (12,167 bonds and 3,356 stocks). We of course acknowledge that using such industry classification entails limitations, as all securities issued by a company are then assumed to fund the same activity. It means we cannot distinguish within a corporation between "browner" and "greener" projects, some of which may be funded by dedicated debt instruments.

We map the BICS classification into the TRBC one (see table A.1), which offers the greatest level of granularity. Our objective is here to sort out companies operating mostly in conventional oil and natural gas industries, from companies operating mostly in the coal-related and unconventional fossil fuel industries (such as shale gas, oil sands, arctic drilling etc.). To do

\footnotetext{
18https://www.refinitiv.com/en/financial-data/indices/trbc-business-classification

${ }^{19}$ https: //www.bloomberg.com/professional/product/reference-data/

${ }^{20}$ See Appendix B for the detailed classification.
} 
so , we recover the implicit mapping between the TRBC and BICS classifications by using securities which are reported simultaneously in both datasets. For securities that are registered only in the Bloomberg database (and as such have a BICS industry classification), we then infer to which TRBC industry category they are most likely to belong. ${ }^{21}$ Overall, TRBC and BICS largely overlap: around $75 \%$ of the securities appear in both databases. Adding information from Bloomberg then augments our list with some 3,000 securities.

\section{B. Euro area investors holdings in fossil energy}

Securities holdings statistics (SHS) are collected at the security level by the ECB and Euro area national central banks (constituting the Eurosystem) from custodians and reporting financial institutions. ${ }^{22}$ Data are reported on an end-of-quarter basis from 2013Q4 onwards and are aggregated at the holding sector/holding country level for each country in the euro area (EA): ie. SHS tracks the holdings of each individual security - identified by its ISIN code - as soon as at least one euro is held by at least one euro area investor, e.g., French banks, Spanish insurers, German Pension funds, etc. ${ }^{23}$ The SHS database also includes useful auxilliary information about each security, be it a debt security or a stock, such as the market price, the nominal amount outstanding, coupons and redemption dates (for bonds) or the total market capitalization and number of shares (for stocks). A public version is available on the ECB website along with a detailed documentation on the holdings data collection methodology ${ }^{24}$.

Holder sectors are defined according to the European System of Accounts 2010 (ESA 2010) and their country is defined on a locational basis, i.e., for instance, BNP Paribas Belgium is reported within the Belgian banking sector and BNP Paribas France within the French banking sector. For our purpose, we group the available financial (sub-)sectors (excluding central banks) into three blocks: (i) banks (S_122 in the ESA 2010 classification), (ii) insurance companies and pension funds, in short ICPF (S_128 and S_129), and (iii) asset management firms and all other financial institutions, i.e., mostly investment and mutual funds (S_123, S_124, S_125, S_126, S_127 and $S_{-} 16$ ), which we denote in short AM. For convenience, we label ICPF and AM firms throughout "institutional investors".

We obtain our final dataset by merging our extended list of securities issued by fossil fuel firms worldwide with euro area holdings data from the SHS database. ${ }^{25}$ The merged dataset

${ }^{21}$ See Table A.2 in the Appendix for details of this mapping.

${ }^{22}$ According to Regulation ECB/2012/24 and amended by Regulation ECB/2015/18.

${ }^{23}$ For instance, the database allows to track the holdings of the bond XS1327914062 issued on December, 12, 2015 by the French Oil company Total SA in the portfolios of, e.g., insurance companies in France.

${ }^{24}$ https://www.ecb.europa.eu/stats/financial_markets_and_interest_rates/ securities_holdings/html/index.en.html

${ }^{25}$ The raw database includes a number of negative holdings of individual securities. These are occasionnaly reported in SHS to materialize short sales or lending of securities. We drop them throughout. We also drop a few hundreds positive holdings with a market value below one euro. 
includes 5,743 unique securities (4,485 bonds and 1,258 stocks) issued by 2,157 distinct fossil energy firms worlwide and held in the portfolios of euro area investors at some point between December 2013 and September 2019. Table A.3 provides a breakdown by instrument (bonds vs stocks) and by source (either Refinitiv or Bloomberg) of these euro area holdings. The Refinitiv and Bloomberg lists of fossil fuel securities account each for some EUR 520 billion of investments by euro area investors.

\section{Descriptive Statistics}

This merged dataset provides us with interesting new insights on the funding of the fossil energy industry by European investors. As of September 2019, euro area investors collectively held some EUR 600 billion of securities issued by fossil fuel companies (see Figure 1). The area's investors thus account for some $12 \%$ of the total market funding of these companies, which amounted at that time to some EUR 4,900 billion (see table A.3). ${ }^{26}$ Among euro area investors, financial institutions unsurprinsingly own the lion's share of these portfolios. As shown by figure 2 , above $80 \%$ of the euro area exposure to fossil energy securities is concentrated in the area's financial sector. Furthermore, their "brown" investments have been on a rising trend, at least up to September 2018. Over the period from 2013 Q4 to 2019 Q3, euro area financial institutions indeed increased their market funding to global fossil fuel firms by EUR 111 billion, from EUR 377 billion to around EUR 488 billion. This notwithstanding, investments into firms specialized in coal and unconventional fuels account for only a tiny share of the total, and remain quite stable at around EUR 10 bns throughout the period. Figure 3 shows that the bulk of these funds flow into firms located in a limited number of countries, mostly in Europe, North America including Mexico and Russia. As of September 2019, 44\% of the fossil portfolios of euro area financial institutions are invested in three countries, the USA, France and the Netherlands, while issuers located in only ten countries -over 80 destinations- account for three quarters of holdings. Last, the fossil fuel investments of euro area financial institutions are also largely concentrated in a few global companies: three European major oil companies benefited alone from some EUR 107 billion of funding in September 2019, some 22\% of total holdings, while 20 issuers (over 1117) received nearly a half of this total funding.

In the remainder of this study, we focus on holdings by euro area financials only. Table 1 provides descriptive statistics about the securities included in our baseline regression sample. The sample consists of 524,689 observations, for 5,629 unique securities (4,460 bonds and 1,169 stocks), issued by 2,057 distinct companies. The average "individual" holding of one

\footnotetext{
${ }^{26}$ Note that the SHS database by construction ignores securities which are not held at all in the euro area. This total therefore underestimates the total market value of all fossil fuel in the world, including for instance Chinese companies that would be entirely owned and funded by Chinese investors.
} 
security (at the holding sector-country level) hoovers at EUR 20 million, but the median value of individual holdings is ten times smaller. For bonds, we report statistics on the yield to maturity (with a median of $3.69 \%$ over our period) and the residual maturity (median residual maturity around 10 years).

Figure 4 shows fluctuations in the average price of fossil energy securities over the period of study, rebased at 100 in December 2015. The figure compares the average price of securities held by treated institutions vs institutions in the control group. The average prices of securities held in these two portfolios roughly moved in synch from 2013 to 2019, which suggests that the list of included securities is similar across groups. Importantly however, average prices surged at the beginning of 2017, in line with the boom in European and global stock markets at the time (which dwarves fluctuations in bond prices). This points to the importance of including controls for price fluctuations at the security level in our regressions, which we do in different ways.

Last, figure 5 gives a preview of our main evaluation exercise in the spirit of a difference in differences framework, which we present formally in the next section. The figure compares the cumulated amounts (at market value) of fossil energy securities held by "treated" institutions (French ICPF and asset management firms) with amounts held by "control" institutions (French banks and all types of financial institutions in all other euro area countries). Both time series are scaled at 100 in Decembre 2015, just before the French disclosure regulation is enacted. While both series arguably comove before this date, the figure shows that they diverge afterwards: the market value of holdings by "treated" investors is then set on a decreasing trend from 2017 on (in spite of the booming stock markets), while the holdings of control financial institutions in the euro area keep on an increasing trend.

\section{Empirical models}

We present formally in this section the baseline empirical model which we estimate to evaluate the impact of the new French regulation on climate-related disclosure by investors. Remember that the intuition for our analysis is a triple difference in differences, whereby we compare the holdings of fossil-energy securities in the portfolios of treated holding sectors (institutional investors) in the country where the new regulation applies (France), with holdings in the portfolios of all financial sectors in all other euro-area countries as well as the non-treated sector (banks) in France, before and after the implementation date of the treatment (January 2016, when the French law of December 2015 enters into force).

Our observation unit is the amount held of a given security $i$ by a given holding sector $h$ of a given country $c$ at the end of quarter $t$. We are first interested in changes in the outstanding 
amounts invested. Accordingly, the baseline model we estimate to assess the impact of the 2015 French regulation on the intensive margin of fossil-energy security holdings reads as follows:

$$
\begin{aligned}
b_{i h s t} & =\beta_{1} P O S T_{t} \times{\operatorname{Inst} I n v_{h}} \times F R_{c} \\
& +\beta_{2} P O S T_{t} \times F R_{c}+\beta_{3} P O S T_{t} \times \text { InstInv }_{h}+\beta_{4} \text { InstInv }_{h} \times F R_{c} \\
& +\gamma_{i}+\gamma_{t}+\gamma_{c}+\gamma_{h}+u_{i h s t}
\end{aligned}
$$

where $b_{\text {ihst }}$ is the market value (in log) of portfolio holdings of security $i$ by institutional sector $h$ of country $c$ at time $t, P O S T_{t}$ denotes the post-treatment period from January 2016 to September $2019, F R_{c}$ is a dummy variable that takes the value of one when the holders of security $i$ are located in France and InstInv ${ }_{h}$ is a dummy variable that takes the value of one when the holder sector is an institutional investor (i.e., here, either an ICPF or an AM, not a bank). The $\gamma$ 's are additional dummy variables that control respectively for the average value of holdings of security $i$, quarterly macroeconomic (euro area-wide) shocks, the average value of holdings in country $c$ and in sector $h$. The main coefficient of interest is $\beta_{1}$, which we expect to be negative since we assume that the new regulation should lead French institunional investors to decrease their investments in fossil-energy securities. Note that we correct the standard deviations of the coefficients' estimators for plausible auto-correlation of the residuals by clustering the covariance matrix of residuals within the dimension of the treatment (i.e., we define clusters as country-sector pairs).

In more constrained specifications of the same baseline set-up, we saturate the model with richer combinations of fixed effects, such as country-holder sector, country-time, holder sectortime and even time-varying shocks at the ISIN level (with yearly frequency only so as to save degrees of freedom). We are therefore able to control effectively for structural features and national specifics that may impinge on the average investment levels of different sectors in fossil energy securities, as well as for whatever unspecified shocks may affect portfolio holdings, such as national macroeconomic or market shocks, shocks to the European financial firms holding these bonds and stocks and shocks to the supply of each security. Last, in one specification, we also add the (log) price of $i$ among right-hand side variables, as a way to control for changes in outstanding amounts that would be driven by price fluctuations. Note that we also conduct complementary analyses using constant-price market values or cross-sectional variations with ISIN-level fixed effects so as to ascertain whether observed changes in outstanding amounts of held fossil-energy securities reflect foremost changes in quantities (disinvestments) or price fluctuations. 
Furthermore, we also want to have a say on the extensive margin of the change in investment behaviour possibly caused by the new disclosure regulation. For this purpose, we consider all possible combinations $(c, h, t)$ of country, sector and date for each security $i$ that is observed at least one quarter in the portfolio of at least one financial sector of one euro area country. We then estimate a similar model as before and explain the probability of holding fossil energy securities by running linear regressions such as:

$$
\begin{aligned}
I_{\left(b_{i h s t}>0\right)} & =\beta_{1} P O S T_{t} \times I_{n s t I n v_{h}} \times F R_{c} \\
& +\beta_{2} P O S T_{t} \times F R_{c}+\beta_{3} P O S T_{t} \times I n s t I n v_{h}+\beta_{4} I_{\text {Inst Inv }} \times F R_{c} \\
& +\gamma_{i}+\gamma_{t}+\gamma_{c}+\gamma_{h}+u_{i h s t}
\end{aligned}
$$

where $I_{\left(b_{i h s t}>0\right)}$ is an indicator variable that takes the value of one whenever we observe a positive holding of $i$ in the portfolio of sector $h$ in country $c$ at time $t$, and zero otherwise. As for the intensive margin of fossil energy investments, we also consider various alternative specifications with richer sets of fixed effects. We also expect here $\beta_{1}$ to be negative since the new French regulation should induce a lower probability of local institutional investors investing in the securities of highly GHG-emitting firms.

\section{Results}

We discuss in this section the results of our empirical investigations in details. We first present the results of the baseline microeconometric analysis, followed by a series of robustness checks. We then deepen the analysis and shed light on differentiated effects across types of fossil fuels, types of securities and types of institutional investors. Last, we look for evidence of an home bias in the response of treated investors.

\section{A. Baseline results}

We first look at the effects of the new disclosure requirements along the intensive margin of investments into fossil energy companies. Table 2 shows the estimation results of equation (1). Column (1) corresponds to the baseline specification, while columns (2) to (4) include step by step more stringent sets of fixed effects. Controlling for simple security, time, country and sector fixed effects yields the expected negative estimate of the main coefficient of interest, $\beta_{1}$, which measures the relative impact of the climate disclosure regulation on the treated holder sector-country pairs. The impact then grows stronger and becomes much more significant (now at the $1 \%$ level) whenever one controls for heterogenous average invested amounts across institutional sectors of different countries by adding sector-country fixed effects. Further, the 
estimate of $\beta_{1}$ remains quite stable when all possible unobserved demand and supply shock are also controlled for by including country, sector and security fixed effects interacted with time.

Note that in our preferred specification, the most stringent one shown in column (4), the effects of fluctuations in the price of individual securities are largely absorbed by the ISIN $\times$ Year fixed effects. This is confirmed in column (5), where we also include among regressors the current price of the security (in log). As expected, the elasticity of outstanding amounts held in portfolio to price changes is almost equal to one (since the market value is the product of quantity and price). However, explicitely controlling for price changes at the level of the individual security does not affect our measure of the policy impact on holdings of fossil energy securities. This confirms that the observed coefficient truly accounts for (relative) disinvestments out of fossil fuel companies by the French institutional investors, which reduced the volumes of such securities in their portfolio after 2015 (either sold them or did not roll over their portfolios by purchasing similar securities after redemption), net of price effects. Further, column (6) shows the results of within regressions, where the identification now comes entirely from changes in holdings of a given security by a given investing sector-country pair. This shrinks the sample to securities that are held throughout by each sector-country pair and notably ignores the contribution to the intensive margin of portfolio changes all the reinvestment choices into the same or similar companies after the redemption of a given brown security. Even in this case however, the effect of the mandatory disclosure comes out as strongly negative, although smaller by one fifth.

Our estimate of the policy impact is economically quite significant. A coefficient of -0.496 implies that holdings of fossil energy securities by French institutional investors is lower by $39 \%$ on average after 2015 , relative to what would have been the case absent the policy. To get a sense of the implied magnitude expressed in euros, let us consider the value of French institutional investors' investments into fossil energy as of the end of 2015, around EUR 71 bns. An average cut by $39 \%$ therefore points to some EUR 28 bns of fundings that have been (on average) redirected out of this industry by French insurance companies and investment funds.

Last, Figure 6 shows the estimated coefficients of interest for a dynamic version of equation (1), where InstInv $v_{h} \times F R_{c}$ is interacted with yearly dummies instead of the Post $_{t}$ indicator. The precise specification of the estimated equation is otherwise the same as in column (4) of Table 2 above. The figure confirms that pre-policy trends were identical for treated and control sectorcountry pairs, which vindicates our identification strategy. Furthermore, it comes out that, after a transition in the first year of enforcement of the new regulation, the average impact on holdings of fossil energy securities remains roughly constant from 2017 onward, corresponding to a cut in invested amounts by some $40 \%$ on average in 2019 compared to the amount held in 
2015 (i.e., $\left.1-e^{-0.51}\right)$.

Climate-burdening investments may be adjusted by decreasing holdings of fossil energy securities (the intensive margin) but also by banning such securities altogether out of the portfolios of treated actors (the extensive margin). Table 3 therefore presents additional results of linear probability regressions that we estimate in order to assess the extensive margin of the policy impact (see equation (2) above). As explained above, we evaluate the probability that a given sector-country pair holds a given fossil energy security at a given point in time against the universe of all possible combinations for all the securities that are registred at least once in the SHS database. We find that the new disclosure policy caused a reduction by $2.3 \%$ of the probability of holding such a security. The effect still holds when controlling for time-varying shocks at the investing sector and coutry levels, but it becomes then only marginally significant.

\section{B. Robustness}

We check the robustness of our findings along several dimensions. First, our results may hinge on the inclusion within the group of controls of the investors of a given country, which may face after 2015 some unobserved, confounding policy change (e.g., some fiscal treatment) that may lead to relative increases in their exposures to fossil energy. Although we are not aware of any national policy in the euro area (excluding France) that would systematically foster fossil energy investments after 2015, we test for the robustness of our baseline regression results when sequentially excluding each of the largest countries in terms of the total portfolio size of their domestic financial industry. ${ }^{27}$ As table 4 shows, the estimate of the main coefficient of interest remains roughly unchanged whatever the excluded country in the control group.

Beyond, we provide further evidence that the observed reduction in holdings caused by the new disclosure policy reflects changes in volumes, i.e., real disinvestments, and not confounding declines in the prices of the securities held in portfolios. For this purpose, we express holdings at constant prices, so that $b^{C} P_{i h s t}=b_{i h s t}-\ln \left(P_{i} t\right)+\ln \left(P_{i, 2015 Q 4}\right)$, where $P_{i, 2015 Q 4}$ is the market price of $i$ at the end of December 2015, and run again similar regressions as in equation (1) and table 2. Table 5, columns (1) to (6), shows the results. Again, the estimated $\beta_{1}$ coefficient barely changes, although the point estimate is slightly smaller than before (in absolute value).

Last, one may worry that the significativity of our main result may be lower than what we claim, due to potential serial correlation of the residuals that is pervasive in differencein-differences-type panel regressions (Bertrand et al., 2004). Although this concern should be

${ }^{27}$ Beyond France, the largest holder countries are Germany, Italy, Luxemburg, the Netherlands, Ireland and Belgium. Together, these 7 countries account for $75 \%$ of observations in our sample and some $90 \%$ of holdings of fossil energy securities at the end of 2015. 
alleviated in our baseline regressions by the use of clustered standard-errors in the dimension of the treatment (i.e., the holder sector-country level), we also run for robustness a cross-sectional regression, whereby we collapse the time dimension into two 3-years periods (2013-2015 vs 2016-2019), take the average of holdings values within each period and compute the growth rate across periods to get our dependent variable. In such a set-up, changes in (period-average) prices are absorbed by the ISIN fixed effects, while demand shocks are absorbed by the country and holder sector fixed effects. As shown in column (7) of table 5, the estimate of the coefficient of interest (now the coefficient of InstInv $\times F R$ ) is roughly the same as before, and still strongly significant.

\section{Extensions}

We now go beyond the main results and first enrich the baseline specification of the empirical model in order to shed light on potentially differentiated effects of the new disclosure policy along several dimensions of the data. The results are summarized in table 6, where all regressions include the most stringent sets of fixed effects as controls (see columns 4 and 5 of table 2 above).

Firstly, we compare the impact of the new disclosure regime on holdings of securities issued by more or less polluting energy companies, as gauged by the type of fossil fuels they produce. Columns (2) and (3) show that the impact is about twice larger for investments in companies exploiting coal and unconventional fossil fuels (such as artic drilling, shale gas, oil sands etc.), which are responsible for larger GHG emissions and overall environmental damages.

Secondly, we also find that disinvestments go through the shedding of stocks rather than bonds out of portfolios (columns 4 and 5). Thirdly, we look for possibly different reactions of the French insurers (and pension funds -ICPF) and asset managers (AM). As column (6) shows, the latters' reaction is about twice larger than the formers' and more significant.

Finally, we ask ourselves whether all issuers, whatever their nationality, are treated in the same way by investors when they have to comply with a more severe climate-related disclosure policy. In other words, does some sort of home bias tilt the reaction of investors? To answer this question, we compare in the last two columns of table 6 the estimated treatment effect we get when focusing on holdings of securities issued either by non-euro area (or "foreign") fossil energy companies or by euro area ones. We find strong evidence in support of an home bias, since the reaction of treated investors is 3.5 times larger when it comes to reducing their exposure to non-euro area issuers. This is consistent with the results of Boermans and Galema (2020), who show that European investors exhibit a strong EU-home bias and refrain from divesting from carbon-intensive stocks when these are issued by EU firms. ${ }^{28}$

${ }^{28}$ See also Bolton and Kacperczyk (2020a) 


\section{Conclusion}

In this paper, we provide evidence that institutional investors tend to decrease the carbon footprint of their portfolios when they are forced to disclose detailed climate-related information about their investments. We exploit for identification a French law that requires insurance companies, pension funds and asset management firms to disclose annually a wide range of information on both their exposure to climate-related risks and their strategy to contribute to mitigating climate change. This law has been enforced since January 2016. We compare the investment behaviour of French institutional investors, which have to abide by this law, with all other unaffected financial institutions in the euro area and find that this disclosure requirement led affected institutions to cut sharply their holdings of securities issued by fossil fuel companies, everything else equal. We prove that the identified change in holdings does not reflect price fluctuations of individual securities, but real divestments out of companies in this highly emitting sector. Interestingly, these relative portfolio adjustments are prone to home bias, as treated institutions priorily shed securities issued by non-euro area fossil energy companies.

Two main policy implications of this research stand out, which seem to us to be of interest in the context of the ongoing efforts to renew the EU strategy for sustainable finance. First, the relative effect that we identify after 2016 still holds out at the end of our sample in 2019, although many large financial institutions in Europe have joigned coalitions of investors committing to fight against climate change in recent years. ${ }^{29}$ This suggests that, while voluntary moves for enhanced carbon disclosure are welcome, more stringent regulations on carbon reporting are of the essence to effectively speed up the alignment of finance with transition needs.

Second, the French law requires institutional investors to provide wide-ranging information on their climate-related risks and the alignment of their portfolio with climate mitigation goals (or to explain why they cannot comply), but in the same time let them free to choose on each item both the methodology and metrics. A lesson from this experiment is therefore that even loosely defined carbon reporting standards may be enough to get a real effect on investment decisions. However, whether such reporting requirements would benefit from being standardized, and to what extent, remains an open issue (on the stronger effects of standardized carbon reporting requirements, see for instance Jouvenot and Krueger, 2020).

\footnotetext{
${ }^{29}$ See for instance the list of signatories of the TCFD (https://www. fsb-tcfd.org/), the Portfolio Decarbonation Coalition (https://unepfi.org/pdc/members/) or of the Climate Action 100+ (http: //www. climateaction $100.0 \mathrm{rg} /$ ) an initiative launched by the Global investor coalition on climate change (GIC).
} 


\section{References}

ACPR, AMF, MEF-DGT, and MTES-CGDD, June 2019, Bilan de l'application des dispositions du décret No. 2015-1850 du 29 décembre 2015 relatives au reporting extra-financier des investisseurs, tech. rep.

Berg, Florian, Julian Koelbel, and Roberto Rigobon, 2019, Aggregate Confusion: The Divergence of ESG Ratings, Working paper 5822-19, MIT Sloan School of Management.

Bertrand, Marianne, Esther Duflo, and Sendhil Mullainathan, 2004, How Much Should We Trust Differences-In-Differences Estimates?, The Quarterly Journal of Economics 119.1, 249-275.

Boermans, Martijn and Rients Galema, 2020, Carbon home bias of European investors, mimeo, De Nederlandsche Bank.

Boermans, Martijn A. and Rients Galema, 2019, Are pension funds actively decarbonizing their portfolios?, Ecological Economics 161, 50 -60.

Bolton, Patrick and Marcin Kacperczyk, 2020a, Carbon risk premium around the world, mimeo, Columbia University of New York.

Bolton, Patrick and Marcin Kacperczyk, 2020b, Do Investors Care about Carbon Risk?, NBER Working Papers 26968, National Bureau of Economic Research, Inc.

Cardona, M., J. Evain, and M. Nicol, 2018, Article 173: Overview of climate-related financial dislosure after two years of implementation, Climate brief 59, I4CE.

Christensen, Hans B., Eric Floyd, Lisa Yao Liu, and Mark Maffett, 2017, The real effects of mandated information on social responsibility in financial reports: Evidence from minesafety records, Journal of Accounting and Economics 64.2, 284-304.

Crifo, Patricia and Bernard Sinclair-Desgagné, 2014, The Economics of Corporate Environmental Responsibility, International Review of Environmental and Resource Economics 7.34, 279-297.

Delis, Manthos, Kathrin de Greiff, and Steven Ongena, 2018, Being Stranded on the Carbon Bubble? Climate Policy Risk and the Pricing of Bank Loans, Swiss Finance Institute Research Paper Series 18-10, Swiss Finance Institute.

Downar, Benedikt, Jürgen Ernstberger, Hannes Rettenbacher, Sebastian Schwenen, and Aleksandar Zaklan, 2019, Fighting Climate Change with Disclosure? The Real Effects of Mandatory Greenhouse Gas Emission Disclosure, Discussion Papers of DIW Berlin 1795, DIW Berlin, German Institute for Economic Research.

Dyck, Alexander, Karl Lins, Lukas Roth, and Hannes Wagner, 2019, Do institutional investors drive corporate social responsibility? International evidence, Journal of Financial Economics 131.3, 693-714. 
Gibson, Rajna and Philipp Krueger, 2017, The Sustainability Footprint of Institutional Investors, Swiss Finance Institute Research Paper Series 17-05, Swiss Finance Institute.

Gibson, Rajna, Simon Glossner, Philipp Krueger, Pedro Matos, and Tom Steffen, 2020, Responsible Institutional Investing Around the World, Swiss Finance Institute Research Paper Series 20-13, Swiss Finance Institute.

Goldstein, Itay and Yaron Leitner, 2018, Stress tests and information disclosure, Journal of Economic Theory 177.C, 34-69.

Goldstein, Itay and Haresh Sapra, 2014, Should Banks' Stress Test Results be Disclosed? An Analysis of the Costs and Benefits, Foundations and Trends $(R)$ in Finance 8.1, 1-54.

Goldstein, Itay and Liyan Yang, 2017, Information Disclosure in Financial Markets, Annual Review of Financial Economics 9.1, 101-125.

Greenstone, Michael, Paul Oyer, and Annette Vissing-Jorgensen, 2006, Mandated Disclosure, Stock Returns, and the 1964 Securities Acts Amendments, The Quarterly Journal of Economics 121.2, 399-460.

Hong, Harrison, Andrew Karolyi, and Jose Scheinkman, 2020, Climate Finance, Review of Financial Studies 33.3, 1011-1023.

Ilhan, Emirhan, Zacharias Sautner, and Grigory Vilkov, 2020, Carbon Tail Risk, tech. rep.

Ioannou, Ioannis and George Serafeim, 2017, The Consequences of Mandatory Corporate Sustainability Reporting, Harvard Business School Working Papers 11-100, Harvard Business School.

Jayaraman, Sudarshan and Joanna Shuang Wu, 2019, Is Silence Golden? Real Effects of Mandatory Disclosure, Review of Financial Studies 32.6, 2225-2259.

Jouvenot, Valentin and Philipp Krueger, 2020, Mandatory coporate carbon disclosure: evidence form a natural experiment, mimeo, University of Geneva.

Kleimeier, Stefanie and P. M. Viehs, 2018, Carbon disclosure, emission levels, and the cost of debt, Research Memorandum 003, Maastricht University, Graduate School of Business and Economics (GSBE).

Koelbel, Julian, Markus Leippold, Jordy Rillaerts, and Qian Wang, 2020, Does the CDS Market Reflect Regulatory Climate Risk Disclosures?, mimeo, University of Zurich.

Leitner, Yaron, 2014, Should regulators reveal information about banks?, Business Review Q3, $1-8$.

Novethic, 2017, 173 Nuances de reporting, tech. rep.

Ramelli, Stefano, Elisa Ossola, and Michela Rancan, 2020, Climate Sin Stocks: Stock Price Reactions to Global Climate Strikes, mimeo, University of Zurich.

Raynaud, Julie, Stephane Voisin, Peter Tankov, Anuschka Hilke, and Alice Pauthier, 2020, The Alignment Cookbook - A Technical Review of Methodologies Assessing a Portfolio's 
Alignment with Low-carbon Trajectories or Temperature Goal, Special report, Institut Louis Bachelier (in partnership with I4CE, WWF, MTES).

SEI, IISD, ODI, Climate Analytics, CICERO, and UNEP, 2019, The Production Gap: The discrepancy between countries' planned fossil fuel production and global production levels consistent with limiting warming to 1.5 degree 2 degree C., tech. rep.

Stigler, George, 1963, Public Regulation of the Securities Markets, The Journal of Business 37. WWF, 2017, Reporting de l'article 173 (vi): des épargnants lost in translation!, tech. rep. 
FIgURE 1. Fossil energy securities holdings in the euro area

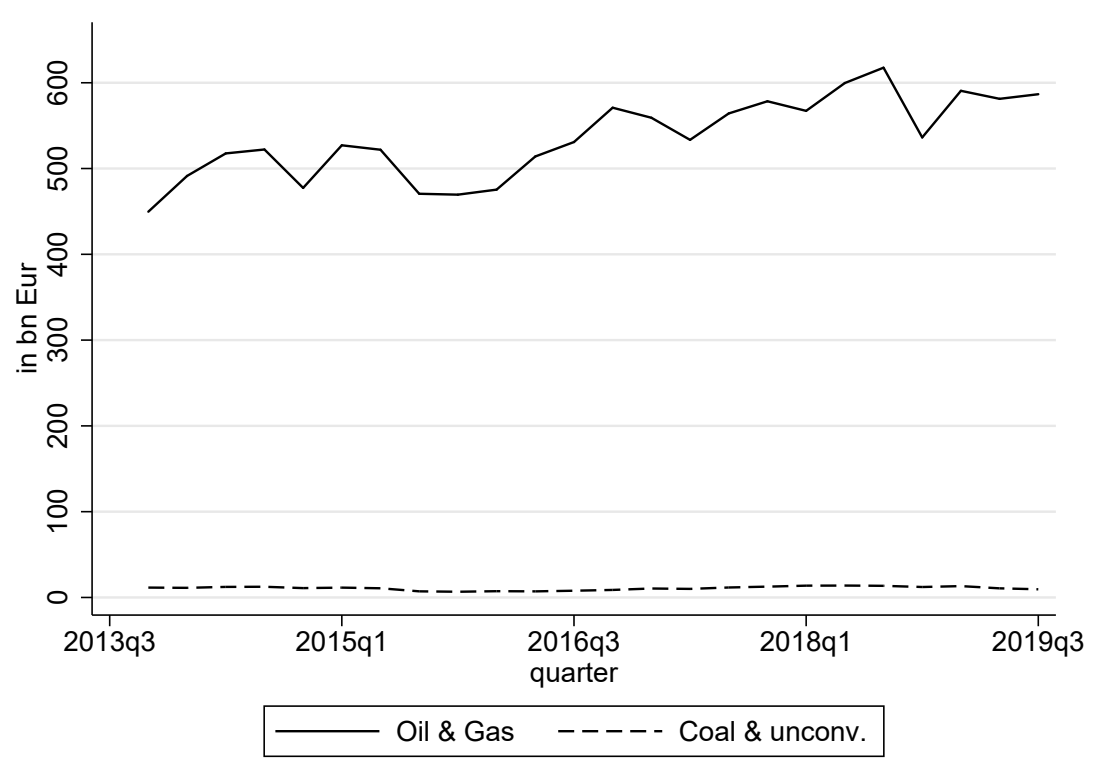

Note. Holdings of bonds and stocks reported by euro area investors (all sectors) in the SHS database. Current market value. 
FIGURE 2. Fossil energy investments of euro area investors: breakdown by holder sector

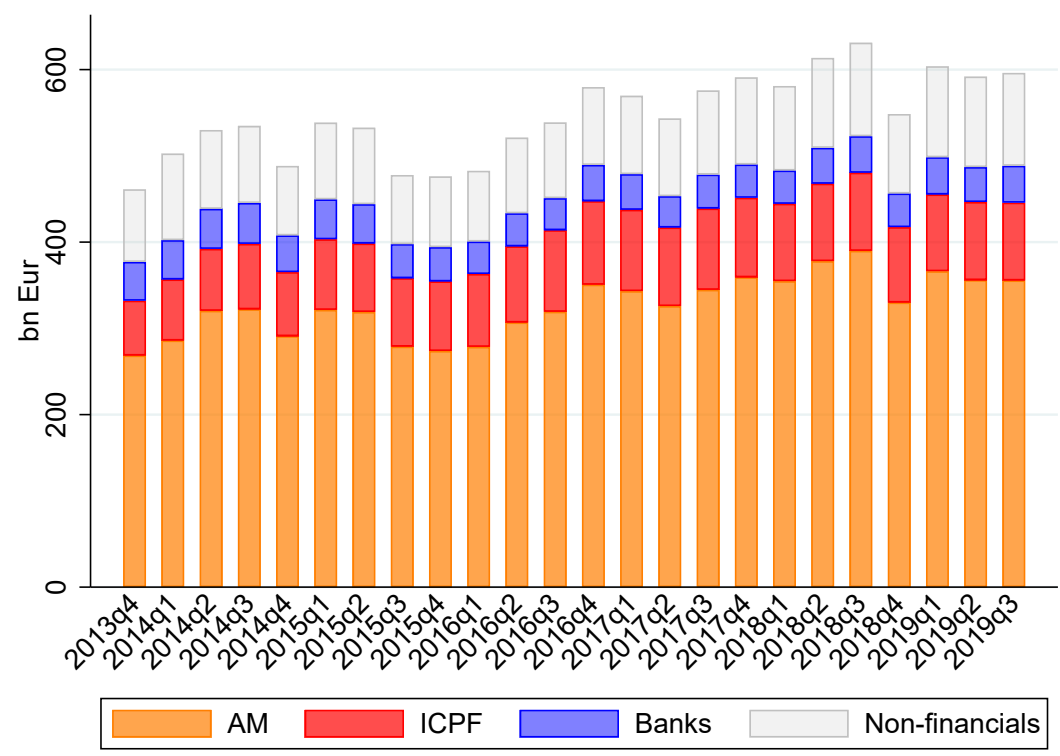

Note. Holdings of bonds and stocks reported by Euro area investors, breakdown by holder sector. Current market values. Non-financials include households, non-financial corporations and governement entities.

FIGURE 3. Fossil energy investments of euro area financial institutions: breakdown by country of destination

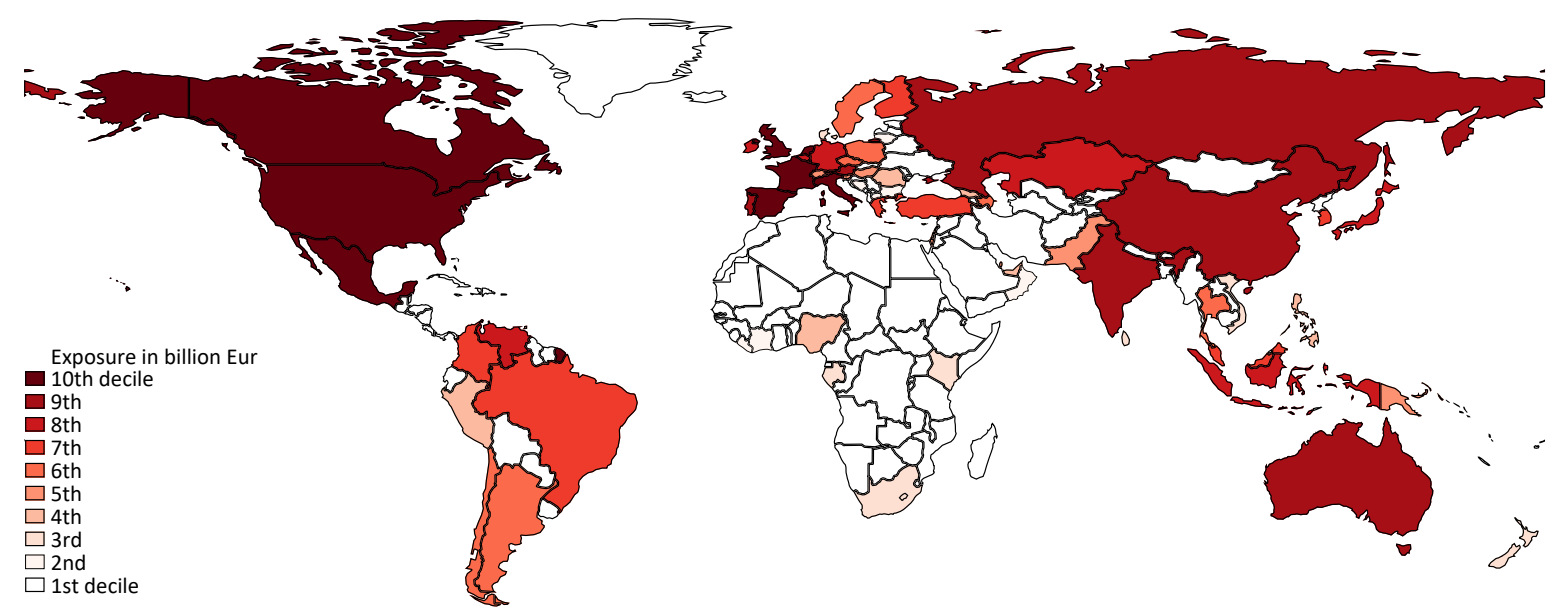

Note. Holdings of fossil energy securities by euro area financials are cumulated at the level of the country of residence of issuer companies. Countries are grouped into deciles of holding amounts. Countries in the last decile benefit from the largest amounts invested by euro area financials. Holdings are expressed at market value as of 2015 Q4. 
FIGURE 4. Average price of fossil energy securities held in portfolio, treated vs control financial institutions $(2015 \mathrm{Q} 4=100)$

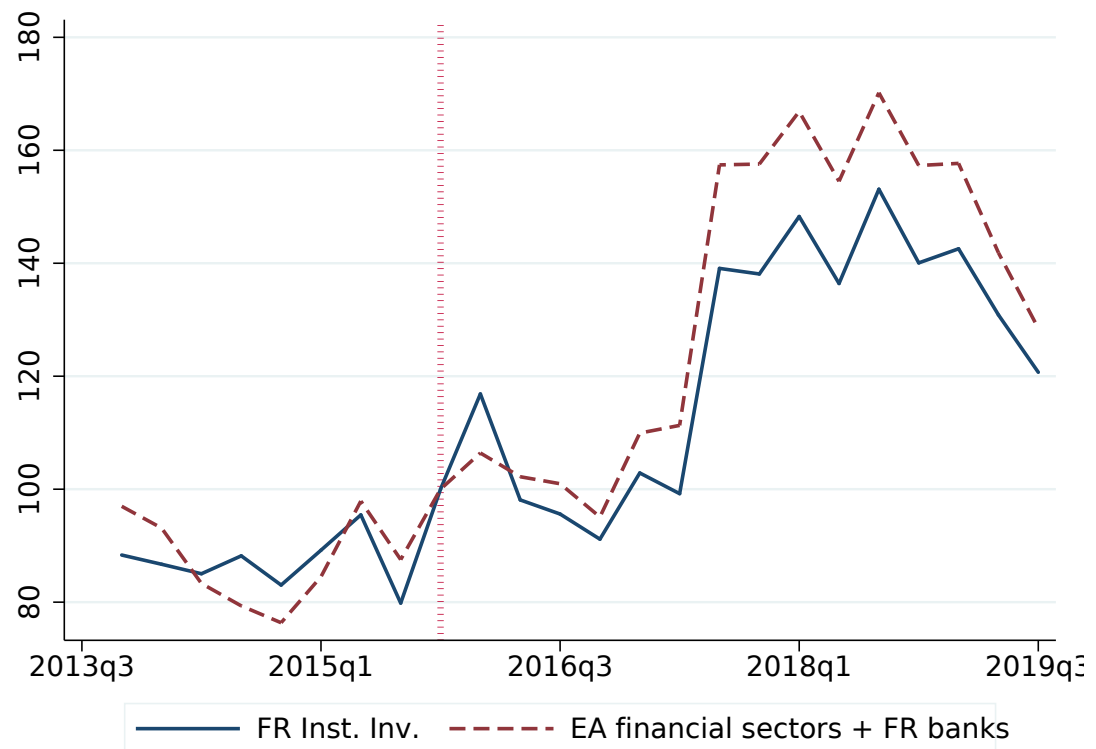

Note. This figure compares the (unweigted) average price of fossil energy securities held by "treated" institutions (French ICPF and AM firms) vs securities held by "control" institutions (French banks and all types of financial institutions in all other euro area countries). Both time series are scaled at 100 in Decembre 2015 (vertical dotted line), just before the French disclosure regulation is enacted. Prices are expressed at market value in euro. 
FIGURE 5. Cumulated holdings of fossil energy securities, treated vs control financial institutions $(2015 \mathrm{Q} 4=100)$

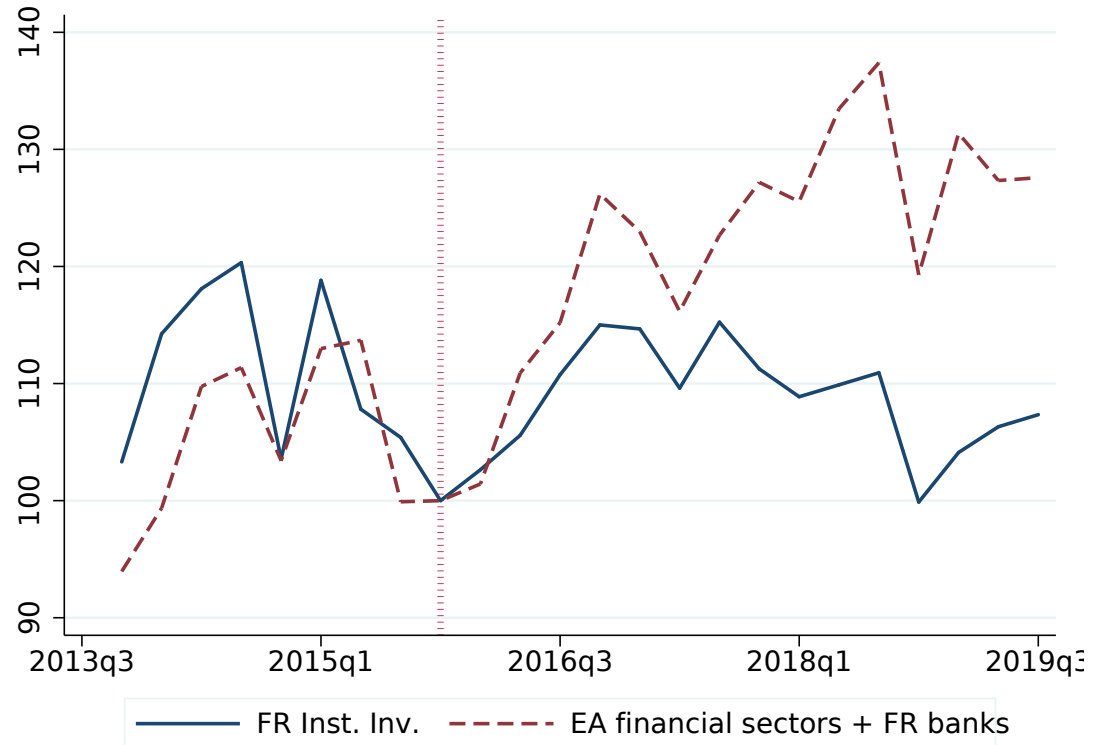

Note. This figure compares amounts of fossil energy securities held by "treated" institutions (French ICPF and AM firms) with amounts held by "control" institutions (French banks and all types of financial institutions in all other euro area countries). Both time series are scaled at 100 in Decembre 2015 (vertical dotted line), just before the French disclosure regulation is enacted. Holdings are expressed at market value. 
FIGURE 6. Estimated impact of the 2015 French regulation on climate-related disclosure: dynamic specification

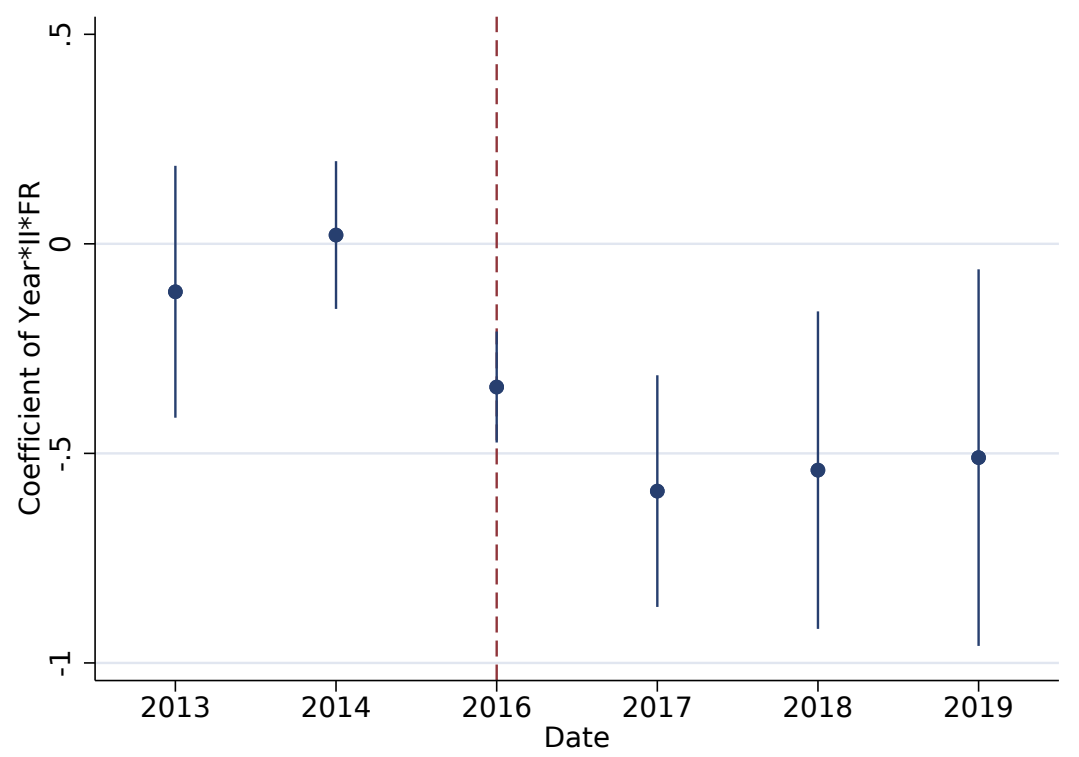

Note. This figure shows the estimated coefficients of the triple interaction terms Year $\times$ InstInv $\times$ FR in a dynamic version of equation (1). 2015 is taken as a reference year and hence omitted. The vertical dotted line in 2016 corresponds to the year when the new climate-related disclosure regulation was enacted in France. 
TABLE 1. Summary statistics - cleaned sample

\begin{tabular}{lcccccccc}
\hline \hline \multicolumn{1}{c}{ Variable } & Obs & Mean & Std. Dev. & Min & Max & P25 & P50 & P75 \\
\hline Holdings (Mn Eur) & 524689 & 20.73 & 194.63 & 0 & 19407.3 & .39 & 2.09 & 10.11 \\
Log Holdings & 524689 & 14.34 & 2.61 & 0 & 23.69 & 12.87 & 14.55 & 16.13 \\
Bond price & 386883 & 101.38 & 15.95 & .05 & 189.25 & 99.25 & 103.04 & 107.9 \\
Stock price & 137806 & 2256.28 & 19668.95 & 0 & 424750 & 5.21 & 22.4 & 66.25 \\
Log Price & 524689 & 4.16 & 1.58 & -9.21 & 12.96 & 4.38 & 4.62 & 4.68 \\
Period return (ann.) & 482283 & -.01 & .58 & -3.92 & 11.68 & -.12 & 0 & .11 \\
Yield-to-maturity (bonds) & 364979 & 4.08 & 3.18 & -1.5 & 20 & 1.79 & 3.69 & 5.57 \\
Resid. maturity (yr, bonds) & 386852 & 11.27 & 8.76 & .49 & 100.08 & 7 & 10 & 10.33 \\
\hline
\end{tabular}

TABLE 2. Impact of the French climate disclosure regulation on holdings of fossil energy securities: intensive margin

\begin{tabular}{lcccccc}
\hline \hline & $(1)$ & $(2)$ & $(3)$ & $(4)$ & $(5)$ & $(6)$ \\
\hline Post $\times$ InstInv $\times$ FR & $-0.363^{*}$ & $-0.484^{* *}$ & $-0.522^{* * *}$ & $-0.496^{* * *}$ & $-0.494^{* * *}$ & $-0.383^{* * *}$ \\
& {$[0.202]$} & {$[0.190]$} & {$[0.169]$} & {$[0.153]$} & {$[0.153]$} & {$[0.095]$} \\
Post $\times$ FR & 0.065 & 0.120 & 0.147 & & & \\
& {$[0.146]$} & {$[0.136]$} & {$[0.125]$} & & & \\
Post $\times$ InstInv & 0.170 & $0.262^{*}$ & $0.286^{* *}$ & & & \\
& {$[0.151]$} & {$[0.141]$} & {$[0.128]$} & & & \\
InstInv $\times$ FR & -0.369 & & & & & \\
& {$[0.510]$} & & & & $0.959^{* * *}$ & \\
ln $($ Price $)$ & & & & & {$[0.033]$} & \\
& & & & & & \\
\hline ISIN FE & Yes & Yes & & & & \\
Time FE & Yes & Yes & & & & \\
Country FE & Yes & & & & & \\
Sector FE & Yes & & & & & \\
Country $\times$ Sector FE & & Yes & Yes & Yes & Yes & \\
Country $\times$ Time FE & & & & Yes & Yes & Yes \\
Sector $\times$ Time FE & & & & Yes & Yes & Yes \\
ISIN $\times$ Year FE & & & Yes & Yes & Yes & Yes \\
ISIN $\times$ Sect. $\times$ Count. FE & & & & & & Yes \\
Nb clusters & 57 & 57 & 57 & 57 & 57 & 57 \\
Observations & 524,579 & 524,579 & 524,116 & 524,116 & 524,116 & 518,123 \\
Adj. R2 & 0.49 & 0.57 & 0.59 & 0.59 & 0.59 & 0.90 \\
\hline \hline
\end{tabular}

Note. Dependent variable: holdings at market value (in $\log$ ) at the ISIN-holder sector-holding country level. Estimation period: 2013-2019. The 2015 French regulation affects institutional investors in France from January 2016 on. The coefficient of the dummy interaction term Post*InstInv*FR therefore reads directly as our estimate of the effect of the new disclosure regulation. Standard errors are clustered at the holder sector-holder country level. 
TABLE 3. Impact of the French climate disclosure regulation on holdings of fossil energy securities: extensive margin

\begin{tabular}{|c|c|c|c|c|c|}
\hline & (1) & (2) & (3) & (4) & (5) \\
\hline Post $\times$ InstInv $\times$ FR & $\begin{array}{c}-0.023^{* * *} \\
{[0.008]}\end{array}$ & $\begin{array}{c}-0.023^{* * *} \\
{[0.008]}\end{array}$ & $\begin{array}{c}-0.023^{* * *} \\
{[0.008]}\end{array}$ & $\begin{array}{c}-0.023^{*} \\
{[0.012]}\end{array}$ & $\begin{array}{c}-0.014^{* *} \\
{[0.007]}\end{array}$ \\
\hline Post $\times$ FR & $\begin{array}{c}0.017^{* * *} \\
{[0.002]}\end{array}$ & $\begin{array}{c}0.017^{* * *} \\
{[0.002]}\end{array}$ & $\begin{array}{c}0.017^{* * *} \\
{[0.002]}\end{array}$ & & \\
\hline Post $\times$ InstInv & $\begin{array}{c}0.024^{* * *} \\
{[0.008]}\end{array}$ & $\begin{array}{c}0.024^{* * *} \\
{[0.008]}\end{array}$ & $\begin{array}{c}0.024^{* * *} \\
{[0.008]}\end{array}$ & & \\
\hline InstInv $\times$ FR & $\begin{array}{l}-0.109^{*} \\
{[0.058]}\end{array}$ & & & & \\
\hline ISIN FE & Yes & Yes & & & \\
\hline Time FE & Yes & Yes & & & \\
\hline Country FE & Yes & & & & \\
\hline Sector FE & Yes & & & & \\
\hline Country $\times$ Sector FE & & Yes & Yes & Yes & \\
\hline Country $\times$ Time FE & & & & Yes & Yes \\
\hline Sector $\times$ Time FE & & & & Yes & Yes \\
\hline ISIN $\times$ Year FE & & & Yes & Yes & Yes \\
\hline ISIN $\times$ Sect. $\times$ Count. FE & & & & & Yes \\
\hline $\mathrm{Nb}$ clusters & 57 & 57 & 57 & 57 & 57 \\
\hline Observations & 3745869 & 3745869 & 3745869 & 3745869 & 3721188 \\
\hline Adj. R2 & 0.32 & 0.44 & 0.44 & 0.44 & 0.81 \\
\hline
\end{tabular}

Note. Linear probability regressions. Dependent variable: dummy variable for positive holdings at the ISINholder sector-holder country level. The estimation sample includes all possible holder country-sector pairs for each ISIN, at all dates when the security is reported to exist. Estimation period: 2013-2019. The 2015 French regulation affects institutional investors in France from 2016 on. The coefficient of the dummy interaction term Post*InstInv*FR therefore reads directly as our estimate of the effect of the new disclosure regulation. Standard errors are clustered at the holder sector-holder country level. 
TABLE 4. Impact of the climate disclosure regulation on holdings of fossil energy securities: robustness (excluding one control country at a time)

\begin{tabular}{lcccccc}
\hline \hline & \multicolumn{6}{c}{ Excluding in turn one control-country: } \\
& DE & IT & LU & IE & NL & BE \\
\hline Post $\times$ InstInv $\times$ FR & $-0.324^{* *}$ & $-0.493^{* * *}$ & $-0.567^{* * *}$ & $-0.518^{* * *}$ & $-0.451^{* * *}$ & $-0.541^{* * *}$ \\
& {$[0.161]$} & {$[0.170]$} & {$[0.130]$} & {$[0.165]$} & {$[0.156]$} & {$[0.145]$} \\
\hline Country $\times$ Sector FE & Yes & Yes & Yes & Yes & Yes & Yes \\
Country $\times$ Time FE & Yes & Yes & Yes & Yes & Yes & Yes \\
Sector $\times$ Time FE & Yes & Yes & Yes & Yes & Yes & Yes \\
ISIN $\times$ Year FE & Yes & Yes & Yes & Yes & Yes & Yes \\
Nb clusters & 54 & 54 & 54 & 54 & 54 & 54 \\
Observations & 451,857 & 481,864 & 445,302 & 450,905 & 458,532 & 494,012 \\
Adj. R2 & 0.57 & 0.60 & 0.57 & 0.59 & 0.60 & 0.59 \\
\hline \hline
\end{tabular}

Note. Dependent variable: holdings at market value (in $\log$ ) at the ISIN-holder sector-holder country level. Estimation period: 2013-2019. The 2015 French regulation affects institutional investors in France from 2016 on. The

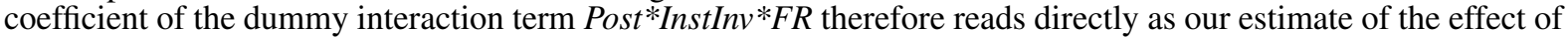
the new disclosure regulation. Standard errors are clustered at the holder sector-holder country level. 
TABLE 5. Impact of the climate disclosure regulation on holdings of fossil energy securities: constant 2015 prices and cross-sectional analysis)

\begin{tabular}{|c|c|c|c|c|c|c|c|}
\hline & \multicolumn{6}{|c|}{ Panel regressions } & \multirow{2}{*}{$\begin{array}{c}\text { CS reg } \\
(7)\end{array}$} \\
\hline & (1) & (2) & (3) & (4) & (5) & (6) & \\
\hline \multirow[t]{2}{*}{ Post $\times$ InstInv $\times$ FR } & $-0.314^{*}$ & $-0.458^{* * *}$ & $-0.492^{* * *}$ & $-0.454^{* * *}$ & $-0.455^{* * *}$ & $-0.364^{* * *}$ & \\
\hline & [0.159] & {$[0.150]$} & {$[0.162]$} & [0.139] & {$[0.139]$} & {$[0.092]$} & \\
\hline \multirow[t]{2}{*}{ Post $\times$ FR } & 0.126 & $0.184^{*}$ & $0.212^{*}$ & & & & \\
\hline & {$[0.112]$} & [0.104] & {$[0.120]$} & & & & \\
\hline \multirow[t]{2}{*}{ Post $\times$ InstInv } & 0.106 & $0.221^{*}$ & $0.254^{* *}$ & & & & \\
\hline & {$[0.117]$} & {$[0.114]$} & {$[0.124]$} & & & & \\
\hline \multirow[t]{2}{*}{ InstInv $\times$ FR } & -0.400 & & & & & & $-0.579^{* * *}$ \\
\hline & {$[0.528]$} & & & & & & {$[0.134]$} \\
\hline \multirow[t]{2}{*}{$\ln$ (Price) } & & & & & -0.025 & & \\
\hline & & & & & {$[0.034]$} & & \\
\hline ISIN FE & Yes & Yes & & & & & Yes \\
\hline Time FE & Yes & Yes & & & & & \\
\hline Country FE & Yes & & & & & & Yes \\
\hline Sector FE & Yes & & & & & & Yes \\
\hline Country $\times$ Sector FE & & Yes & Yes & Yes & Yes & & \\
\hline Country $\times$ Time FE & & & & Yes & Yes & Yes & \\
\hline Sector $\times$ Time FE & & & & Yes & Yes & Yes & \\
\hline ISIN $\times$ Year FE & & & Yes & Yes & Yes & Yes & \\
\hline ISIN $\times$ Sect. $\times$ Count. FE & & & & & & Yes & \\
\hline $\mathrm{Nb}$ clusters & 57 & 57 & 57 & 57 & 57 & 57 & \\
\hline Observations & 411,046 & 411,046 & 410,834 & 410,834 & 410,834 & 408,842 & 21,379 \\
\hline Adj. R2 & 0.50 & 0.58 & 0.59 & 0.59 & 0.59 & 0.90 & 0.09 \\
\hline
\end{tabular}

Note. Dependent variable: holdings expressed at 2015 Q4 market prices (in log) at the ISIN-holder sector-holder country level (col. 1-6), or growth rate of holdings at market prices at the ISIN-holder sector-holder country level (col. 7). In the regression presented in col. 7, growth rates compare the average holdings over 2013-2015 vs 2016-2019. Estimation period: 2013-2019. The 2015 French regulation affects institutional investors in France from January 2016 on. The coefficient of the dummy interaction term Post ${ }^{*} \operatorname{InstInv} * F R$ therefore reads directly as our estimate of the effect of the new disclosure regulation. Standard errors are clustered at the holder sector-holder country level (col. 1-6) or White-robust (col. 7). 
TABLE 6. Impact of the French climate disclosure regulation on holdings of fossil energy securities: complementary analysis

\begin{tabular}{|c|c|c|c|c|c|c|c|c|}
\hline & $\begin{array}{c}\text { Fossil } \\
\text { (1) }\end{array}$ & $\begin{array}{c}\text { Oil/gas } \\
\text { (2) }\end{array}$ & $\begin{array}{c}\text { Coal/Unc. } \\
\text { (3) }\end{array}$ & $\begin{array}{c}(4) \\
\text { Bonds }\end{array}$ & $\begin{array}{c}(5) \\
\text { Stocks }\end{array}$ & $\begin{array}{l}\text { Fossil } \\
(6)\end{array}$ & $\begin{array}{l}(7) \\
\text { For. }\end{array}$ & $\begin{array}{l}(8) \\
\text { EA }\end{array}$ \\
\hline Post $\times$ InstInv $\times$ FR & $\begin{array}{c}-0.496^{* * *} \\
{[0.153]}\end{array}$ & $\begin{array}{c}-0.486^{* * *} \\
{[0.160]}\end{array}$ & $\begin{array}{c}-0.968^{* * *} \\
{[0.311]}\end{array}$ & $\begin{array}{c}-0.050 \\
{[0.121]}\end{array}$ & $\begin{array}{c}-1.264^{* * *} \\
{[0.222]}\end{array}$ & & $\begin{array}{c}-0.699^{* * *} \\
{[0.206]}\end{array}$ & $\begin{array}{l}-0.192^{*} \\
{[0.100]}\end{array}$ \\
\hline Post $\times \mathrm{ICPF} \times \mathrm{FR}$ & & & & & & $\begin{array}{l}-0.291^{*} \\
{[0.164]}\end{array}$ & & \\
\hline Post $\times$ AM $\times$ FR & & & & & & $\begin{array}{c}-0.572^{* * *} \\
{[0.135]}\end{array}$ & & \\
\hline Country $\times$ Sector FE & Yes & Yes & Yes & Yes & Yes & Yes & Yes & Yes \\
\hline Country $\times$ Time FE & Yes & Yes & Yes & Yes & Yes & Yes & Yes & Yes \\
\hline Sector $\times$ Time FE & Yes & Yes & Yes & Yes & Yes & Yes & Yes & Yes \\
\hline ISIN $\times$ Year FE & Yes & Yes & Yes & Yes & Yes & Yes & Yes & Yes \\
\hline $\mathrm{Nb}$ clusters & 57 & 57 & 51 & 57 & 57 & 57 & 57 & 57 \\
\hline Observations & 524,116 & 504,859 & 19,232 & 386,535 & 137,581 & 524,116 & 393,167 & 130,948 \\
\hline Adj. R2 & 0.59 & 0.58 & 0.71 & 0.52 & 0.69 & 0.59 & 0.62 & 0.51 \\
\hline
\end{tabular}

Note. Dependent variable: holdings at market value (in $\log$ ) at the ISIN-holder sector-holder country level. Estimation period: 2013-2019. The 2015 French regulation affects institutional investors in France from 2016 on. The coefficient of the dummy interaction term Post*InstInv*FR therefore reads directly as our estimate of the effect of the new disclosure regulation. Columns 2 and 3 restrict the sample to securities issued by firms of conventional oil/gas industries and coal/unconventional fuel industries respectively. Columns 4-5 look at bonds and equity shares separately. In column 6, the impact on holdings by two subtypes of institutional investors is investigated ICPF (insurance companies and pension funds) vs AM (other mutual funds and hedge funds). In the last two columns, the sample is split into two subsamples, depending on the location of the issuer. For. stands for foreign issuers, i.e. entities outside of the euro area. EA stands for euro area issuers. Standard errors are clustered at the holder sector-holder country level. 
Online appendix - not for publication.

\section{A. Additional tables}

TABLE A.1. Fossil energy classification according to TRBC

\begin{tabular}{|c|c|c|}
\hline TRBC classification & $\begin{array}{r}\text { Oil/Gas } \\
\text { Conv. }\end{array}$ & Coal/Unconv \\
\hline Coal (NEC) & & $\checkmark$ \\
\hline Coal Mining Support & & $\checkmark$ \\
\hline Coal Wholesale & & $\checkmark$ \\
\hline Gasoline Stations & $\checkmark$ & \\
\hline Integrated Oil \& Gas & $\checkmark$ & \\
\hline LNG Transportation \& Storage & $\checkmark$ & \\
\hline Natural Gas Exploration \& Production - Offshore & $\checkmark$ & \\
\hline Natural Gas Exploration \& Production - Onshore & $\checkmark$ & \\
\hline Natural Gas Pipeline Transportation & $\checkmark$ & \\
\hline Oil Drilling - Offshore & $\checkmark$ & \\
\hline Oil Exploration \& Production - Offshore & $\checkmark$ & \\
\hline Oil Exploration \& Production - Onshore & $\checkmark$ & \\
\hline Oil Pipeline Transportation & $\checkmark$ & \\
\hline Oil Related - Surveying \& Mapping Services & $\checkmark$ & \\
\hline Oil Related Equipment & $\checkmark$ & \\
\hline Oil Related Services & $\checkmark$ & \\
\hline Oil Related Services and Equipment (NEC) & $\checkmark$ & \\
\hline Oil \& Gas Drilling (NEC) & $\checkmark$ & \\
\hline Oil \& Gas Exploration and Production (NEC) & $\checkmark$ & \\
\hline Oil \& Gas Refining and Marketing (NEC) & $\checkmark$ & \\
\hline Oil \& Gas Storage & $\checkmark$ & \\
\hline Oil \& Gas Transportation Services (NEC) & $\checkmark$ & \\
\hline Petroleum Product Wholesale & $\checkmark$ & \\
\hline Petroleum Refining & $\checkmark$ & \\
\hline Pyrolytic \& Synthetic Fuels & $\checkmark$ & \\
\hline Sea-Borne Tankers & $\checkmark$ & \\
\hline Stationary Fuel Cells & $\checkmark$ & \\
\hline Unconventional Oil \& Gas Drilling & & $\checkmark$ \\
\hline Unconventional Oil \& Gas Production & & $\checkmark$ \\
\hline Uranium (NEC) & $\checkmark$ & \\
\hline Uranium Mining & $\checkmark$ & \\
\hline
\end{tabular}

Note. TRBC classification from Refinitiv. Split between Oil/Gas/Conventional and Coal/Unconventional is ours. 
TABLE A.2. Mapping between Bloomberg's BICS energy sectors and Refinitiv's TRBC ones

\begin{tabular}{ll}
\hline BICS Level2 & TRBC Activity \\
\hline Coal Operations & Coal (NEC) \\
Exploration \& Production & Oil \& Gas Exploration and Production (NEC) \\
Integrated Oils & Integrated Oil \& Gas \\
Oil \& Gas Services \& Equipment & Oil Related Services and Equipment (NEC) \\
Pipeline & Oil \& Gas Transportation Services (NEC) \\
Refining \& Marketing & Oil \& Gas Refining and Marketing (NEC) \\
\hline
\end{tabular}

Note. This implicit mapping is built from securities classified in both TRBC and BICS according to the most frequent pairs. 
TABLE A.3. Total euro area holdings of fossil fuel securities by source and instrument, market value in billions euro

\begin{tabular}{|c|c|c|c|c|c|c|}
\hline \multirow[b]{2}{*}{ Quarter } & \multicolumn{2}{|c|}{ SHS } & \multicolumn{2}{|c|}{ Instrument } & \multicolumn{2}{|c|}{ Source } \\
\hline & Outstanding & Holdings & Bonds & Stocks & TRBC & BICS \\
\hline $2013 q 4$ & 4077 & 461 & 168 & 293 & 411 & 384 \\
\hline 2014q1 & 4235 & 503 & 183 & 320 & 445 & 421 \\
\hline $2014 q 2$ & 4703 & 530 & 197 & 333 & 469 & 445 \\
\hline $2014 q 3$ & 4764 & 535 & 207 & 328 & 469 & 450 \\
\hline $2014 q 4$ & 4206 & 488 & 203 & 285 & 422 & 416 \\
\hline $2015 q 1$ & 4687 & 539 & 228 & 310 & 467 & 458 \\
\hline $2015 q 2$ & 4445 & 533 & 226 & 307 & 462 & 454 \\
\hline $2015 q 3$ & 3659 & 478 & 214 & 264 & 408 & 408 \\
\hline $2015 q 4$ & 3762 & 476 & 207 & 269 & 406 & 405 \\
\hline $2016 q 1$ & 3795 & 483 & 211 & 272 & 411 & 412 \\
\hline $2016 q 2$ & 4260 & 521 & 228 & 293 & 445 & 447 \\
\hline $2016 q 3$ & 4367 & 539 & 242 & 297 & 455 & 461 \\
\hline $2016 q 4$ & 4984 & 580 & 248 & 331 & 495 & 495 \\
\hline 2017q1 & 4674 & 570 & 250 & 320 & 485 & 492 \\
\hline $2017 q 2$ & 4409 & 543 & 244 & 300 & 461 & 473 \\
\hline 2017q3 & 4530 & 576 & 248 & 328 & 491 & 503 \\
\hline $2017 q 4$ & 4742 & 591 & 247 & 344 & 508 & 515 \\
\hline 2018q1 & 4516 & 581 & 238 & 343 & 501 & 502 \\
\hline $2018 q 2$ & 4994 & 614 & 234 & 380 & 538 & 532 \\
\hline $2018 \mathrm{q} 3$ & 5149 & 631 & 234 & 397 & 556 & 548 \\
\hline $2018 q 4$ & 4398 & 549 & 224 & 324 & 476 & 477 \\
\hline 2019q1 & 5027 & 604 & 233 & 371 & 530 & 525 \\
\hline $2019 q 2$ & 4882 & 592 & 237 & 355 & 516 & 516 \\
\hline $2019 q 3$ & 4894 & 596 & 247 & 350 & 517 & 523 \\
\hline
\end{tabular}

Note. This table reports in column (1) the outstanding of fossil energy securities existing in SHS, ie. which are held for at least 1 euro by an investor resident in the euro area, as well as in column (2) the corresponding total holdings in the euro area. Amounts are expressed at market value. TRBC and BICS refer to the scope of fossil energy companies according to the industry classifications of respectively Refinitiv and Bloomberg. Row totals exceed SHS holdings as in column (2) because of overlaps between the two sources. 


\section{B. Classifications}

\section{A. Bloomberg BICS}

FIGURE 7. Bloomberg BICS classification
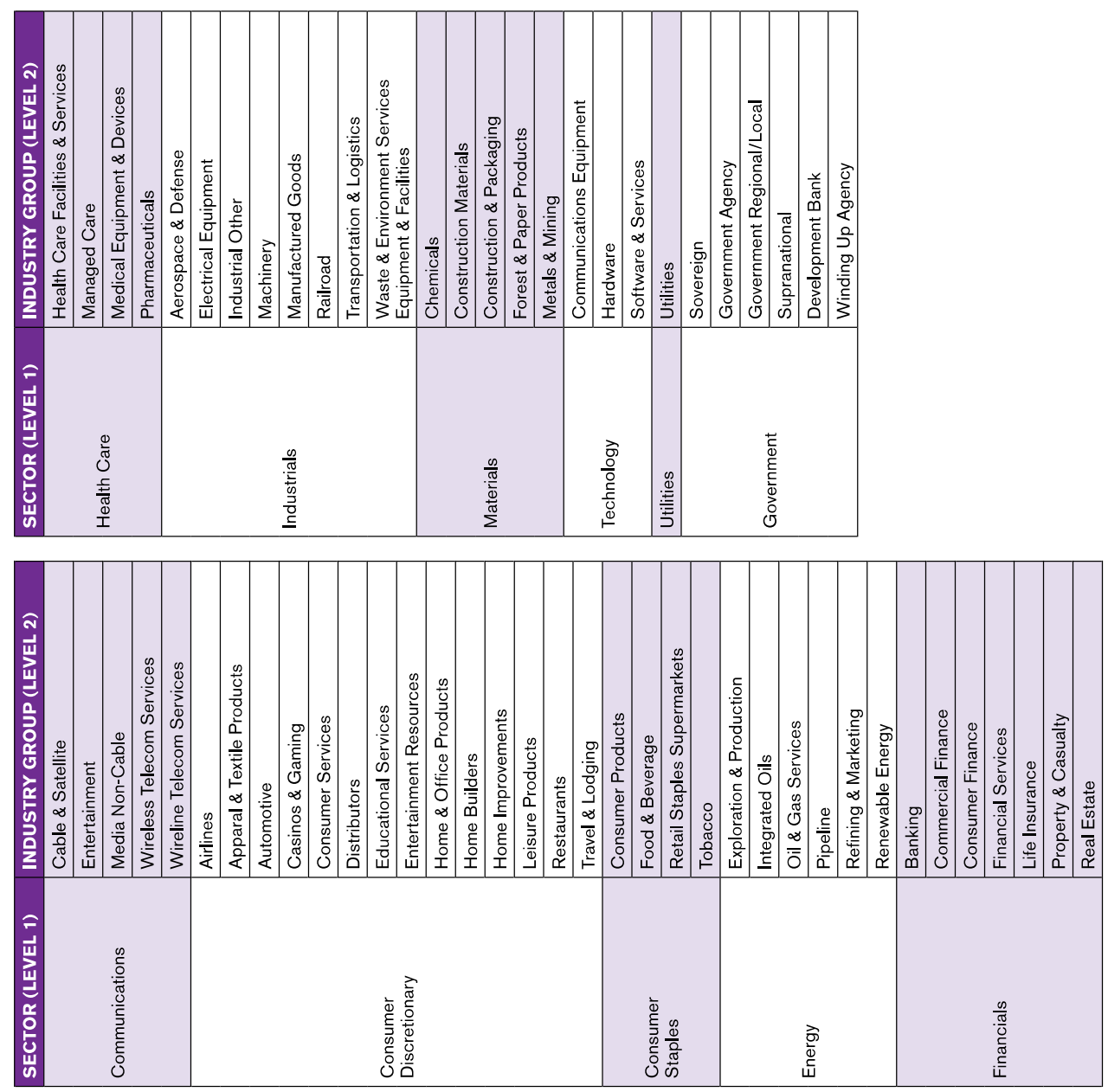

Source: Bloomberg 
B. Refinitiv TRBC

FIGURE 8. Refinitiv TRBC classification - Extract of the energy sector

\begin{tabular}{|c|c|c|c|c|}
\hline ECONOMIC SECTOR & BUSINESS SECTOR & INDUSTRY GROUP & INDUSTRY & ACTIVITY \\
\hline \multicolumn{5}{|l|}{ Energy } \\
\hline & \multicolumn{4}{|l|}{ Energy - Fossil Fuels } \\
\hline & & \multicolumn{3}{|l|}{ Coal } \\
\hline & & & \multirow{2}{*}{\multicolumn{2}{|c|}{ Coal }} \\
\hline & & & & Coal (NEC) \\
\hline & & & & Coal Mining Support \\
\hline & & & & Coal Wholesale \\
\hline & & \multicolumn{3}{|l|}{ Oil \& Gas } \\
\hline & & & \multicolumn{2}{|c|}{ Integrated Oil \& Gas } \\
\hline & & & & Integrated Oil \& Gas \\
\hline & & & \multicolumn{2}{|c|}{ Oil \& Gas Exploration and Production } \\
\hline & & & & Oil \& Gas Exploration and Production (NEC) \\
\hline & & & & Oil Exploration \& Production - Onshore \\
\hline & & & & Oil Exploration \& Production - Offshore \\
\hline & & & & Natural Gas Exploration \& Production - Onshore \\
\hline & & & & Natural Gas Exploration \& Production - Offshore \\
\hline & & & & Unconventional Oil \& Gas Production \\
\hline & & & \multicolumn{2}{|c|}{ Oil \& Gas Refining and Marketing } \\
\hline & & & & Oil \& Gas Refining and Marketing (NEC) \\
\hline & & & & Petroleum Refining \\
\hline & & & & Gasoline Stations \\
\hline & & & & Petroleum Product Wholesale \\
\hline & & \multicolumn{3}{|c|}{ Oil \& Gas Related Equipment and Services } \\
\hline & & & \multicolumn{2}{|c|}{ Oil \& Gas Drilling } \\
\hline & & & & Oil \& Cas Drilling (NEC) \\
\hline & & & & Oil Drilling - Onshore \\
\hline & & & & Gas Drilling - Onshore \\
\hline & & & & Oil Drilling - Offshore \\
\hline & & & & Gas Drilling - Offshore \\
\hline & & & & Unconventional Oil \& Gas Drilling \\
\hline & & & \multicolumn{2}{|c|}{ Oil Related Services and Equipment } \\
\hline & & & & Oil Related Services and Equipment (NEC) \\
\hline & & & & Oil Related Services \\
\hline & & & & Oil Related Equipment \\
\hline & & & & Oil Related - Surveying \& Mapping Services \\
\hline
\end{tabular}

Source: Refinitiv 